\title{
Vegetation diversity on coal mine spoil heaps - how important is the texture of the soil substrate?
}

\author{
Agnieszka Kompała-Bąba ${ }^{1}$ - Wojciech Bierza ${ }^{1} \cdot$ Agnieszka Błońska $^{1}$ (D) Edyta Sierka ${ }^{1} \cdot$ Franco Magurno $^{1}$. \\ Damian Chmura $^{2} \cdot$ Lynn Besenyei $^{3} \cdot$ Łukasz Radosz $^{1} \cdot$ Gabriela Woźniak $^{1}$
}

Received: 16 October 2018 / Accepted: 12 February 2019 / Published online: 28 February 2019

(C) The Author(s) 2019

\begin{abstract}
The relationship between the size of the particle fractions of the soil substrate and the diversity of the spontaneously developing vegetation was investigated on coal mine spoil heaps in Upper Silesia (Southern Poland). The analyses were based on 2567 research plots of developed spontaneous vegetation and their associated soil substrate samples collected from 112 coal mine spoil heaps. For each research plot the prevailing particle size fraction was determined (stones, gravel, sand, silt), the species composition and abundance was recorded and the species richness (S), Shannon-Wiener diversity index ( $\left.\mathrm{H}^{\prime}\right)$, Simpson (C) and Evenness (E) indices were used to determine species diversity. From a total of 119 research plots (in all particle size fraction categories), the values of 15 physicochemical properties $(\mathrm{pH}$, electrical conductivity, water holding capacity, moisture, carbon content, total $\mathrm{N}$, available $\mathrm{P}, \mathrm{Mg}$ and exchange cations $\mathrm{Ca}, \mathrm{Mg}, \mathrm{K}, \mathrm{Na}$, fine particles (\%), gravel (\%), stone (\%)) were obtained to asses their impact on the floristic composition of vegetation patches using Canonical Correspondence Analysis (CCA). Additionally, functional traits of the dominant species of each vegetation patch (life forms, life strategies and socio-ecological groups), were selected to analyse their relation to substrate texture. It was shown that the highest species richness and the highest values for ShannonWiener diversity index, as well as Simpson and Evenness indices, were obtained in plots formed on stones. Moreover, the greatest variation in the participation of species representing different habitats, life forms, and life strategies was found on gravelly substrates. Contrary to our expectations, the vegetation diversity (in terms of both species and their functional traits) was not highest in habitats with a high composition of fine size particles.
\end{abstract}

Keywords Soil texture $\cdot$ Vegetation $\cdot$ Coal mining post-industrial sites

\section{Introduction}

In both natural and semi-natural habitats soil and vegetation, and their associated physicochemical processes, are the two main components of terrestrial ecosystems (Hopmans et al. 2005; Oyonarte et al. 2008). One of the important factors controlling the cycling

Agnieszka Błońska

agnieszka.blonska@us.edu.pl

1 Faculty of Biology and Environmental Protection, University of Silesia in Katowice, Jagiellońska Str. 28, 40-032 Katowice, Poland

2 Institute of Environmental Protection and Engineering, University of Bielsko-Biala, Willowa 2, 43-309 Bielsko-Biała, Poland

3 School of Sciences, Faculty of Science \& Engineering, University of Wolverhampton, Wulfruna Street, Wolverhampton WV1 1LY, UK of nutrients in soils, for primary production of vegetation communities, is the sustained availability of nutrients for plant growth (Schimel and Bennett 2004). However, when used in agriculture, or forestry, single parameters are often insufficient for monitoring soil degradation and desertification as well as for the effective reclamation of the soil substrate of postindustrial sites. The factors influencing soil nutrient availability are one of the first parameters to consider when evaluating soil quality and the recovery of soil substrate function when restoring ecosystem function (Tang et al. 2010). The characteristics of the soil particle fraction are the main indicators of soil-vegetation system feedback (Zhang and Zhao 2009). Some relationships between soil and vegetation have been more deeply studied including the interactions between some tree species, desertification and soil erosion 
(Herrmann and Hutchinson 2005; Chen et al. 2006; Zeng et al. 2009; Li et al. 2016; Song et al. 2016). Some studies also focus on analysis of separate fractions e.g. of gravel, sand or silt or using soil organic carbon (SOC) which is commonly applied to assess soil quality. However, soil is a complex medium in which many biological and physical components interact in space and time (Katz and Thompson 1985; Watkins and Freeman 2008). When considering the intense human pressures on the environment, it is important to understand soil recovery mechanisms and the relationships between post-industrial soils and the development of spontaneous vegetation, particularly for the sustained environmental management of post-industrial sites.

Knowledge of the relationship between soil physicochemical properties and the functions of the spontaneously developing vegetation on post-industrial sites is limited (Gao et al. 2004; Wang et al. 2007). This mutual relationship includes the regulation of water infiltration and its accessibility to the particular vegetation community as well as at the whole ecosystem (Woźniak et al. 2015; Jasik et al. 2017; Strzyżowski et al. 2018). Most studies consider the role of the soil particle size fraction and soil properties on post-industrial sites in the process of reclamation (Martínez-Ruiz et al. 2001; Wang et al. 2011). Few studies have analyzed the effects of the soil particle size fraction on the stability of the soilvegetation system as a result of the restoration processes e.g. Zhang and Zhao (2009). The importance of the fine particle fraction in processes taking place in the soil has been highlighted in many studies (Christensen 2001; Hemkemeyer et al. 2018). The silt fraction (fine particles $<0.05$ ) plays an important role in the retention of soil nutrients and water cycling (Lobe et al. 2001; Zalibekov 2002). Compared to the soil in natural and semi-natural ecosystems, the relationships between the soil particle fractions, water and nutrient availability and the spontaneous vegetation feedback in post-industrial sites are much more complicated and also need to be analyzed for practical restoration purposes. This study focuses on coal mine spoil heaps as a type of post-industrial sites, and these are common in Europe but also in e.g. China, USA and Australia.

The coal mine spoil heaps studied here are located in an urban-industrial landscape in Upper Silesia (Southern Poland). These spoil heaps have substantially different habitat conditions compared with their surroundings and, thus, can be considered as "environmental islands" within the landscape (Tropek et al. 2017; Woźniak et al. 2018). They are formed from carboniferous gangue rocks originating from a depth of about 0.5 to $1 \mathrm{~km}$ below the surface. Due to extreme abiotic conditions (lack of water, low nutrient availability/content, high temperatures, sometimes high salinity, these heaps have been considered to be biological deserts, where living organisms cannot grow, or they colonize very slowly (Bradshaw 1997, 2000; Wiegleb and Felinks 2001; Zhu 2003). In contrast to lead and zinc spoil heaps they do not contain a high concentrations of heavy metals. However, according to field observations these gangue spoil heaps, despite their unfavorable conditions, are effectively colonized by plants and animals with different habitat preferences over time, but, the colonisation processes are multidimensionally related, complicated and still poorly understood (Piekarska-Stachowiak et al. 2014; Tropek et al. 2017; Talik et al. 2018). Long term studies of the spontaneously developed vegetation on post-coal mine sites in Upper Silesia have revealed that the species composition of vegetation patches is based on the abundance of a few dominant plant species accompanied by a number of much less abundant species (Woźniak 2003; Woźniak and Cohn 2007; PiekarskaStachowiak et al. 2014). According to the "mass ratio" hypothesis (Grime 1979) dominant species play the driving role in ecosystem functioning processes and some of the analyses of relationships between vegetation diversity and soil texture are focused exclusively on the trait characteristics of the dominant species (e.g. Prach and Pyšek 1999).

In order to evaluate the relationship between the soil particle sizes of coal mine spoil heaps and the vegetation diversity which has developed during the process of spontaneous succession, a more general approach has been adopted in this research. A large number of samples (2567) enabled us to classify the granulometry of vegetation patches based on the prevailing particle size fraction (stone, gravel, sand, silt) present in the research plot. We hypothesized that species richness as well as values for diversity indices would be highest in vegetation patches with a higher participation of fine particles (silt) in the soil substrate, as such sites can potentially retain water and soil organic carbon more efficiently.

The aims of the study were to: (1) examine how the soil substrate particle fraction varies with reference to the different vegetation types; (2) determine the influence of other physicochemical properties on the floristic composition of vegetation patches, (3) determine the relationship between the soil substrate texture and the selected traits of the dominant plant species found within the vegetation patches on coal mine spoil heaps. 


\section{Materials and methods}

\section{Site description}

A total of 112 coal mine spoil heaps belonging to 61 coal mines that were the objects of this research are located in the Silesian Upland in Southern Poland (Fig. 1). These spoil heaps can be divided in terms of age into four groups: up to $10 \mathrm{yr}$; up to $30 \mathrm{yr}$.; up to $60 \mathrm{yr}$. and more than $60 \mathrm{yr}$. The youngest heaps are only a few years old while the oldest are more than 100 years old (Woźniak 2010). The region of the Silesian Upland is under the influence of a temperate climate. Here, the main annual rainfall is $600-800 \mathrm{~mm}$ and the highest mean temperature in July is $14-16^{\circ} \mathrm{C}$. The area is dominated by western winds, particularly from a south-westerly direction. Cloud cover in the area of the Silesian voivodeship is around $60-80 \%$. The number of days with mists ranges from 30 to over 100 (Skurczyńska and Leśniok 2008). The spoil heaps were formed by storing the geologically homogeneous rock material, such as carboniferous gangue into tall piles (Cabała et al. 2004). The stored rock material consists of clays, mudstones, and to a lesser extent sandstones, gravels and coal shales. The chemical composition of the waste affects the formation of secondary products such as chlorides and sulphates (Pieczyrak 2010). Spoil heaps can also be characterized by a high salinity (Szczepańska 1987; Woźniak 2010).
Generally, they are not contaminated by heavy metals. On the surface of the spoil heaps, the temperature can sometimes be very high reaching up to more than $50{ }^{\circ} \mathrm{C}$, which may be associated with the high heat conduction of these rocks (Patrzałek 2001).

\section{Sampling of vegetation data}

The main field studies were conducted between 1998 and 2007 (additional detailed sampling and analysis have been conducted in subsequent years). Data on the vegetation that developed spontaneously on the coal mine spoil heaps were collected along the widest possible spectrum of variation within the habitat conditions (data on vegetation in space). For this purpose, a grid of vertical and horizontal lines was placed on each heap. The lengths of the vertical and horizontal lines of the grids were $50 \mathrm{~m}$ each. The vertical grid lines were in a north-south direction and the horizontal lines were in an eastwest direction. Research plots were established in patches that were located at the intersection of the vertical and horizontal lines. They were graded as either: (i) herbaceous and shrub vegetation with an area $\geq 16 \mathrm{~m}^{2}$ and an abundance of shrubs and young trees under $\geq 30 \%$ or (ii) patches of forest vegetation with an area $\geq 100 \mathrm{~m}^{2}$ and a cover of trees $\geq 30 \%$. In total 2567 research plots were established. In each plot, all rooted vascular plant species were recorded and their percentage

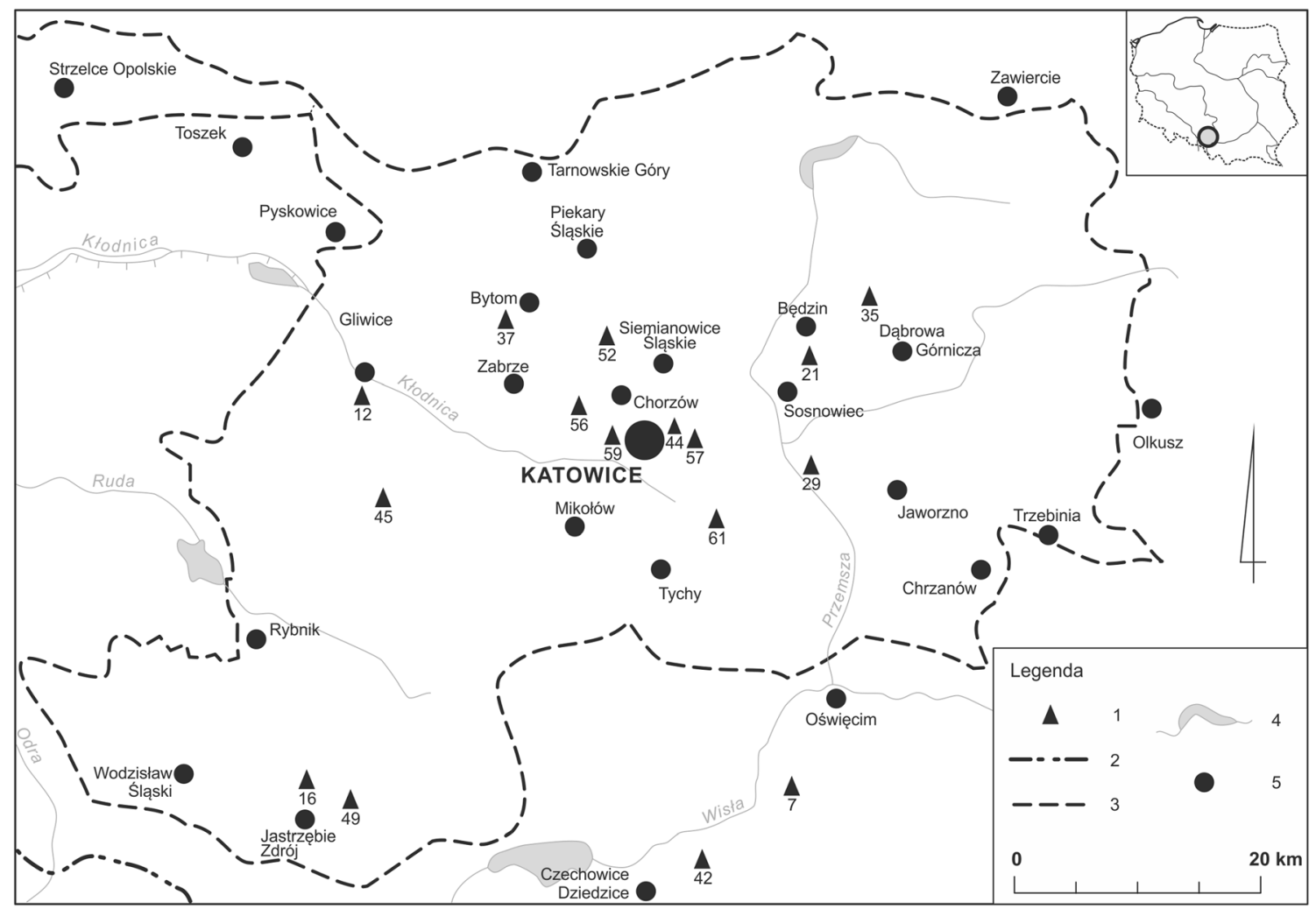

Fig. 1 Distribution of coal mines and their spoil heaps in the region of the Silesian Upland in southern Poland: 1 - coal mines (112 coal mine heaps belonging to 61 coal mines); 2 - state border; 3 - border of the Silesian Upland; 4 - rivers and lakes; 5 - towns and cities 
cover was estimated visually according to abundance classes: $<1 \%, 1-5,5-10,10-20,20-30 \%$ and then every $10 \%$. The plot size was $4 \times 4 \mathrm{~m}^{2}$ for herbaceous and shrub vegetation and $10 \times 10 \mathrm{~m}^{2}$ for forest vegetation.

The nomenclature of vascular plants followed that of Mirek et al. (2002).

\section{Species and plant trait diversity}

For each research plot a dominant species determining the physiognomy of the vegetation patch was identified and was further analyzed in terms of its species traits. Moreover, the chosen functional traits of the dominant species were used in the classification of vegetation patches with reference to the coarseness of the substrate.

The dominant plant species were characterized by defining their affiliation to one of the socio-ecological groups according to Oberdorfer et al. (1990) that reflect their habitat classification known from their natural and semi-natural habitats. In the results section the dominant species groups are referred to as socio-ecological groups which were defined as: (B and L) - forest species: B (Class Vaccinio-Piceetea) and L - (Cl. Querco- Fagetea, Alnetea glutinosae); LK - meadow species ( $\mathrm{Cl}$. Molinio-Arrhenatheretea); (MK and MP) - grassland species: MK - (K1. Festuco-Brometea) and MP - (Cl. Sedo-Scleranthetea, Nardo-Callunetea); NS - species of rock habitats - karst species $(\mathrm{Cl}$. Asplenietea, Violetea calaminariae, Thlaspietea), $\mathrm{O}$ - species of clearings and thermophilous fringes ( $\mathrm{Cl}$. Epilobietea angustifolii, Trifolio-Geranietea); RD - ruderal species (C1. Artemisietea, Agropyretea, Plantaginetea, Agrostietea stoloniferae); S - salt marsh species ( $\mathrm{Cl}$. Zosteretea, Ruppietea, Asteretea tripolii, HonckenyoElymetea, Cakiletea, Ammophiletea); SG - segetal species - (Cl. Chenopodietea, Secalietea); TR peatbog and bog species (Cl. Montio-Cardaminetea, Scheuchzerio-Caricetea, Oxycocco-Sphagnetea); WN and $\mathrm{W}$ - rush and aquatic species: $\mathrm{WN}-(\mathrm{Cl}$. Phragmitetea, Isoeto-Nanojuncetea, Bidentetea tripartitae) and $\mathrm{W}$ ( $\mathrm{Cl}$. Lemnetea, Utricularietea, Potametea).

Additionally, for each dominant species in a plot the following traits were identified: life forms (Zarzycki et al. 2002): T - terophytes, G - geophytes, H hemicryptophytes, C - chamaephytes, N nanophanerophytes, M - mega-phanerophytes; life strategies (Grime 1979; Frank and Klotz 1990; Klotz et al. 2002): C - competitors; S - stress-tolerant species; R ruderal species; CR - competitive-ruderal species; SR stress tolerant species; CSR - intermediate life strategy; CS - competitive and stress tolerant species.
Species richness (S) and measures of diversity such as Shannon-Wiener diversity index $\left(\mathrm{H}^{\prime}\right)$, Evenness $(\mathrm{E})$ and Simpson's index of dominance $(\mathrm{C})$ were used and calculated for each of the research plots based on the presence and abundance of plant species constituting a given research plot. The indices were calculated using the Juice 7.0 computer programme (Tichý and Holt 2006).

\section{Soil substrate analysis}

In order to examine the coarseness of the substrate in the research plots we collected samples from a depth of 10-15 cm (root zone). Subsequently, the granulometric composition of each sample was determined according to PN ISO 11277:2005 as a fraction of: stones (> $75 \mathrm{~mm})$, gravel $(2-75 \mathrm{~mm})$, sand $(0.05-$ $2 \mathrm{~mm})$ or silt $(<0.05 \mathrm{~mm})$. The substrate samples were dried at room temperature to an air-dry state. Agglomerated fragments were crushed in a porcelain mortar. The samples were then sieved through a $2 \mathrm{~mm}$ sieve. The percentage share of skeletal parts (> $2 \mathrm{~mm}$ ) (stones and gravel) was determined by sieving, while the share of finer particles $(<2 \mathrm{~mm}$ ) (sand and silt) was determined by an aerometric method which consisted of comparing the density of a dispersed soil suspension with a comparative solution during sedimentation of the soil fractions. Both, the tested and the comparative solutions were kept at room temperature $\left(18-22{ }^{\circ} \mathrm{C}\right)$, and the difference between the solutions was not greater than $\pm 0.5{ }^{\circ} \mathrm{C}$.

Moreover, for a given substrate type, we chose 30 plots (119 in total) for determination of other physicochemical parameters: $\mathrm{pH}$, electrical conductivity (EC), water holding capacity (WHC), moisture, carbon content (TOC), total $\mathrm{N}(\mathrm{TN})$, available $\mathrm{P}, \mathrm{Mg}, \mathrm{Ca}, \mathrm{Na}, \mathrm{K}$. Soil $\mathrm{pH}$ was measured in $1 \mathrm{M} \mathrm{KCl}$ and $\mathrm{EC}$ in water suspension (Bednarek et al. 2004). The Tiurin method was applied to assess the total carbon content (TOC) (Ostrowska et al. 1991). TN was determined by the Kjeldahl method (Rutherford et al. 2006). The content of available phosphorus was based on the Egner-Riehm method (PN-R-04023:1996), whereas the content of available $\mathrm{Mg}$ was measured by spectrometric analysis (Ostrowska et al. 1991). The content of available phosphorus was based on the Egner-Riehm method (PN-R04023:1996), whereas the content of available $\mathrm{Mg}$ was measured by spectrometric analysis (Ostrowska et al. 1991). Content of exchangeable $\mathrm{K}^{+}, \mathrm{Na}^{+}, \mathrm{Mg}^{2+}$ and $\mathrm{Ca}^{2+}$ was measured according to methodology proposed by Simard (1993) using atomic absorption spectroscopy (Appendix 1). 


\section{Data analysis}

A constrained ordination CCA (Canonical Correspondence Analysis) was used in order to (i) relate the species composition of the vegetation to the soil particle size and (ii) to characterize and visualize the relationship between the floristic composition of vegetation plots and measured physicochemical soil variables. In order to select a set of measured environmental variables which explain the floristic differentiation of the vegetation in the best way, the forward selection procedure available in CANOCO 4.5 was used. It started with a null model with no predictors and an assumption that there was no variability in the species data. Next, the consecutive explanatory variables were added and their significance was tested with the use of a Monte Carlo permutation test (999 permutations) (ter Braak and Šmilauer 2012). In order to compare substrates in terms of species diversity indices the Kruskal-Wallis test and the Siegel-Castellan test for pair-wise comparisons were used. The differences in frequency of dominants representing chosen plant traits among substrates were examined by means of contingency Tables ( $\mathrm{G}$ test). All statistical analyses were undertaken using the R language ( $\mathrm{R}$ Core Team 2018). Spearman rank correlations between soil fractions and other physicochemical parameters were calculated using Statistica 13.1 software (Dell Inc 2016) to find the relationship between soil texture and other physicochemical parameters.

\section{Results}

\section{The relationship between vegetation plots, dominant species and substrate texture}

The CCA (Fig. 2), with subsequent k-means clustering, revealed three groups of species in the plots related to the predominance of particular fractions such as gravel, sand and silt. A fourth group comprised plots populated by dominant species which were strongly related to the stone fraction. In our study area most vegetation patches (1572) occurred on substrate with high gravel fractions. A total of 106 dominant species were found in these patches and occurred with an average frequency of $14.83 \%$ on this type of substrate (Appendix 2). Dominant species that were present in more than 50 vegetation patches on this substrate type included: Betula pendula (present in 113 patches), Calamagrostis epigejos (162), Daucus carota (81), Chamaenerion palustre (52), Melilotus alba (85), Poa compressa (51), Solidago canadensis (67) and
Tussilago farfara (148). Fewest vegetation patches (160) were found on substrate where the highest fractions of silt were recorded. On this type of substrate, 21 dominant species were found with an average frequency of $7.62 \%$. The vegetation in these patches was dominated most often by two species: Poa compressa (57) and Phragmites australis (33). A similar frequency $(7.79 \%)$ was found for those vegetation patches that were recorded on sandy substrates prevailed. Here the vegetation patches were dominated by Betula pendula (34), Calamagrostis epigejos (71), Polygonum aviculare (35) and Tussilago farfara (48) and had a frequency of over 30 occurrences in the sand fraction substrate. On the substrate with the prevalence of stone fraction prevailed there was a total of 173 vegetation patches which were dominated by Betula pendula (21), Chamaenerion palustre (17), Populus tremula (17) and Tussilago farfara (21).

Eigenvalues Ax I: 0.20, Ax II: 0.19, cumulative explained variation: Ax I: $4.01 \mathrm{Ax}$ II: 7.91.

Species abbreviations: AchMill - Achillea millefolium; AegpPodg - Aegopodium podagaria; AgrsCap - Agrostis capillaris; AgrsStol - Agrostis stolonifera; AmarRetr - Amaranthus retroflexus; ArenSerp - Arenaria serpyllifolia; ArrhElat Arrhenatherum elatius; ArtmVulg - Artemisia vulgaris; BetlPen - Betula pendula; BidnFron - Bidens frondosa; BidnTrip - Bidens tripartita; BracRutD Brachythecium rutabulum; BracVelD - Brachythecium velutinum; BryuArgD - Bryum argenteum; CalmEpig Calamagrostis epigejos; CarxHirt - Carex hirta; CentDiff - Centaurea diffusa; CentJace - Centaurea jacea; CersArvn-Cerastium arvense; ChaeMins Chaenorhinum minus; ChenGlau - Chenopodium glaucum; ChenRubr - Chenopodium rubrum; CirsArvn - Cirsium arvense; ClemVitl - Clematis vitalba; ConzCan - Conyza canadensis; DaucCart - Daucus carota; EchiVulg - Echium vulgare; EchnCrus Echinochloa crus-galli; EpilDodn - Chamaenerion palustre; EquiArvn - Equisetum arvense; ErigAnnu Erigeron annuus; EuptCann - Eupatorium cannabinum; FagsSylc - Fagus sylvatica; FranAlnB - Frangula alnus; GaliMoll - Galium mollugo; HierPils Hieracium piloselloides; HierXF1 -Hieracium xfloribundum; HolcLant - Holcus lanatus; JuncEffs Juncus effusus; LeonAutm - Leontodon autumnalis; LepdCamp - Lepidium campestre; LotsCorn - Lotus corniculatus; MaiaBifl - Maianthemum bifolium; MatrMart - Matricaria maritima subsp. inodora; MedcLupl - Medicago lupulina; MeliAlba - Melilotus alba; MyclMurl - Mycelis muralis; OentBien Oenothera biennis; OentSpec - Oenothera sp.; OrthSecn - Orthilia secunda; OxalAcet - Oxalis 
Fig. 2 CCA diagram of chosen dominants and soil texture

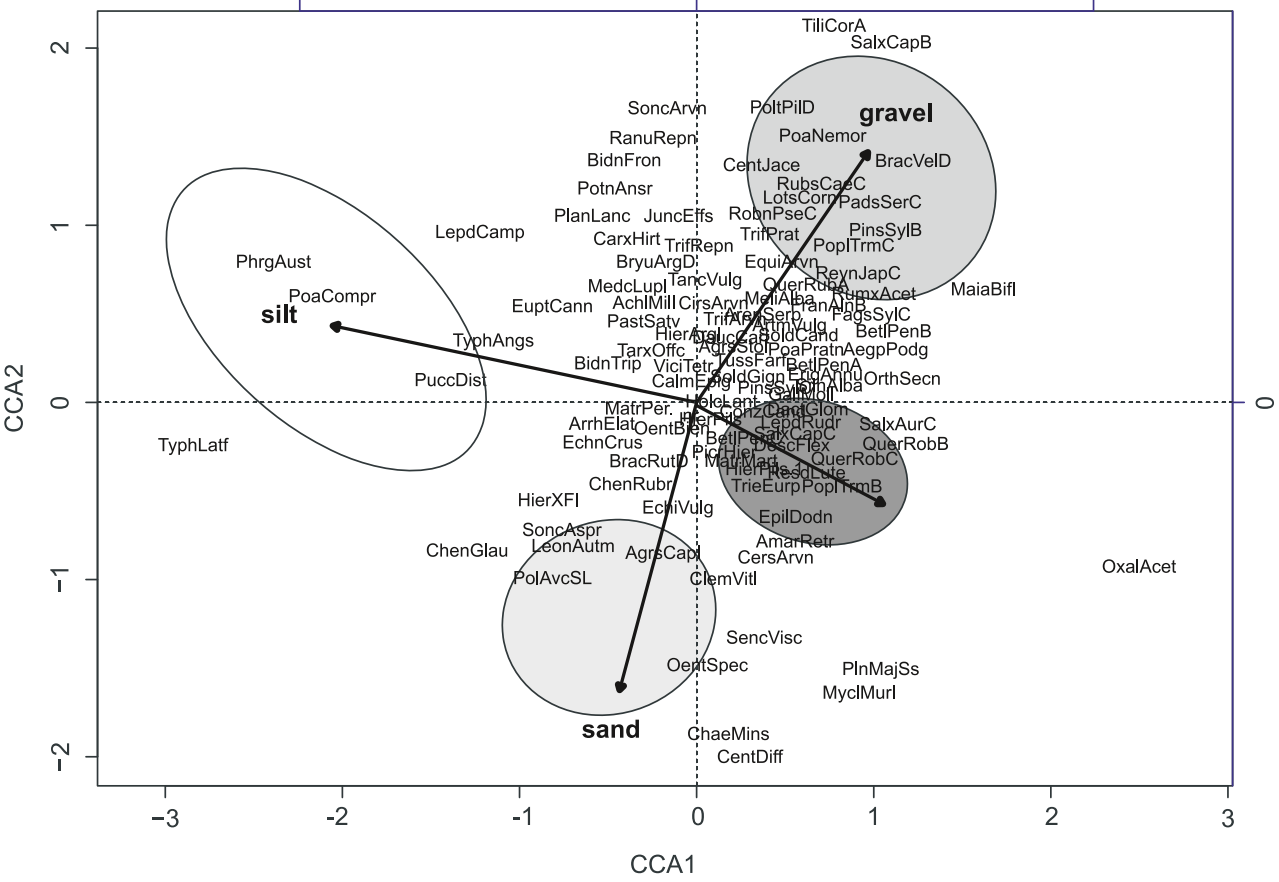

acetosella; PadsSerC - Padus serotina; PastSatv Pastinaca sativa; PhrgAust - Phragmites australis; PicrHier - Picris hieracioides; PinsSyl - Pinus sylvestris; PlanLan - Plantago lanceolata; PlnMajSs Plantago major; PoaCompr - Poa compressa; PoaNemor - Poa nemoralis; PoaPratn - Poa pratensis; PolAvcSL - Polygonum aviculare; PoltPilD Polytrichum piliferum; PoplTrm - Populus tremula; PotnAnsr - Potentilla anserina; PuccDist - Puccinellia distans; QuerRobB - Quercus robur; QuerRubf Quercus rubra; RanuRepn - Ranunculus repens; ReynJopc - Reynoutria japonica; RobnPsec - Robinia pseudoacacia; RubsCaeC - Rubus caesius; RumxAcet - Rumex acetosa; SalxAurC - Salix aurita; SalxCapB Salix caprea; SencVisc - Senecio viscosus; SoldCan Solidago canadensis; SoldGign - Solidago gigantea; SoncArvn - Sonchus arvensis; SoncAspr - Sonchus asper; TancVulg - Tanacetum vulgare; TarxOffc Taraxacum officinale; TiliCorA - Tilia cordata; TrieEurp - Trientalis europaea; TrifArven - Trifolium arvense; TrifPrat - Trifolium pratense; TrifRepn Trifolium repens; TussFarf - Tussilago farfara; TyphAngs - Typha angustifolia; TyphLatf - Typha latifolia; ViciTetr - Vicia tetrasperma.

\section{Species richness and diversity of vegetation patches developed on different substrates}

A total of 440 species was recorded on all studied coal mine spoil heaps. Analysis of the species richness of the vegetation patches which developed in stony and gravelly places revealed differences from those where smaller particle sizes (sand, silt) had a higher share in the substrate (Fig. 3a). The highest average values for species richness were recorded on vegetation patches occurring on stony substrates (mean number of species 10.2) whereas the lowest values (mean number of species 7.18) were recorded for vegetation patches occurring on silty substrates.

These relationships were confirmed by comparing the values of the average Shannon-Wiener diversity index in relation to the particle size of the soil substrate. The analysis showed that there were significant differences between all types of substrates. Plant diversity was the highest $\left(H^{\prime}=\right.$ 4.16) in the patches on stony substrate, whereas the lowest values were for vegetation in the patches found on silty substrates $\left(H^{\prime}=2.64\right)$ (Fig. 3b).

A comparison of Evenness indices of the vegetation in relation to substrate texture on which the patches were recorded (Fig. 3c), revealed that there were significant differences between vegetation patches growing on stony, or gravelly, substrates compared with sandy or silty patches. Highest values were observed in the patches on stony substrates $(\mathrm{E}=$ 0.55 ) and lowest values were for vegetation on substrates with a high silt fraction $(\mathrm{E}=0.45)$.

Notably significant differences were detected for Simpson's dominance index (C) between the vegetation plots on stony and gravelly substrates and silty and sandy substrates. Highest values were observed in the patches on stony substrates $(\mathrm{C}=0.50)$ and lowest values were for vegetation on substrates with a high silt fraction $(\mathrm{C}=0.35)$ (Fig. 3d). 
Fig. 3 (a) Species richness (S) $\mathrm{H}$ $(3,2567)=79.15 ; p<0.001,(\mathbf{b})$ Shannon-Wiener diversity index $\left(\mathrm{H}^{\prime}\right) \mathrm{H}(3,2567)=71.16$; $p<0.001$, (c) Evenness (E) H(3, $2567)=42.66 ; p<0.001$ and $(\mathbf{d})$ Dominance $(\mathrm{C}) \mathrm{H}(3,2567)=$ $58.37 ; p<0.001$ of vegetation patches on spoil heaps depending on the coarseness of the substrate. $S I$ - silt, $S A$ - sand, $G$ - gravel, $S T$ - stones, groups with the same letter are not significantly different from one another. The whisker plot presents the median 1.5 of the quartile range and the circles indicate the outliers
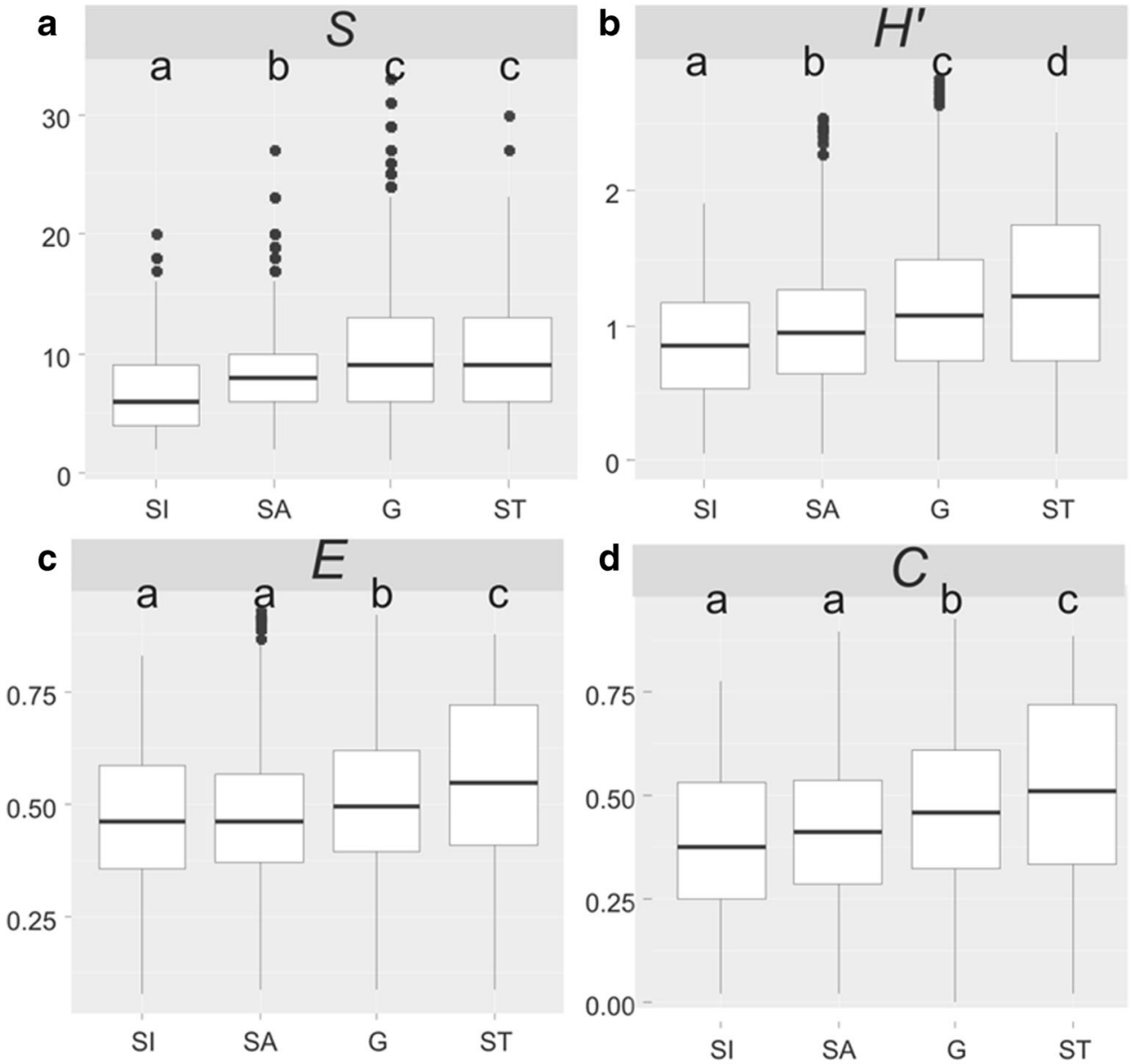

coarseness of the soil substrate

\section{The relationship between significant physicochemical soil variables and floristic composition of vegetation patches}

The CCA analysis (Fig. 4) showed a relationship between the floristic composition of vegetation patches and statistically significant physicochemical variables. All explanatory variables used in the analysis accounted for $18.1 \%$ of the total variation (Table 1). Among 15 analyzed variables taken into analysis, 8 of them made the significant contribution $(15.13 \%)$ to the explanation of the total variation of the dataset (adjusted explained variation is $4.9 \%$ ). Forward selection revealed that soil variables such as available potassium, total carbon content, soil reaction, available magnesium content, water holding capacity, $\mathrm{Na}^{+}, \mathrm{EC}$, as well as the percentage of the finer fraction, made a significant contribution to this variation. We found significant correlations between percentage participation of the finer fraction with soil moisture, water holding capacity, magnesium content in the soil substrate; share of the gravel fraction and available magnesium (negative correlation) and $\mathrm{K}^{+}$content and a negative relationship between exchangeable $\mathrm{Ca}^{2+}, \mathrm{K}^{+}$content and of stone fraction percentage.

Species such as: Sanguisorba minor, Phleum pratense, Cardaminopsis arenosa, Petrorhagia prolifera, Melilotus alba, Agrostis stolonifera, Hieracium laevigatum, Senecio viscosus were associated with a higher content of $\mathrm{K}^{+}$. Species associated with a higher content of WHC\% were: Dipsacus sylvestris, Lythrum salicaria, Calystegia sepium, Phleum pratense, Petrorhagia prolifera, Epilobium parviflorum, Puccinellia distans, Galeopsis tetrahit, Rubus caesius, Urtica dioica, Leontodon autumnalis, Filago arvensis, Plantago major. Species associated with a higher $\mathrm{pH}$, as well as high percentage of small particles were: Solidago virgaurea, Apera spica-venti, Fallopia convolvulus, Crepis biennis, Reseda lutea, Artemisia vulgaris. Species associated with a high carbon content (TOC) in the soil were: Sonchus asper, Agrostis vinealis, Chaenorhinum minus, Senecio vulgaris, Hieracium umbellatum, Chamaenerion palustre. 


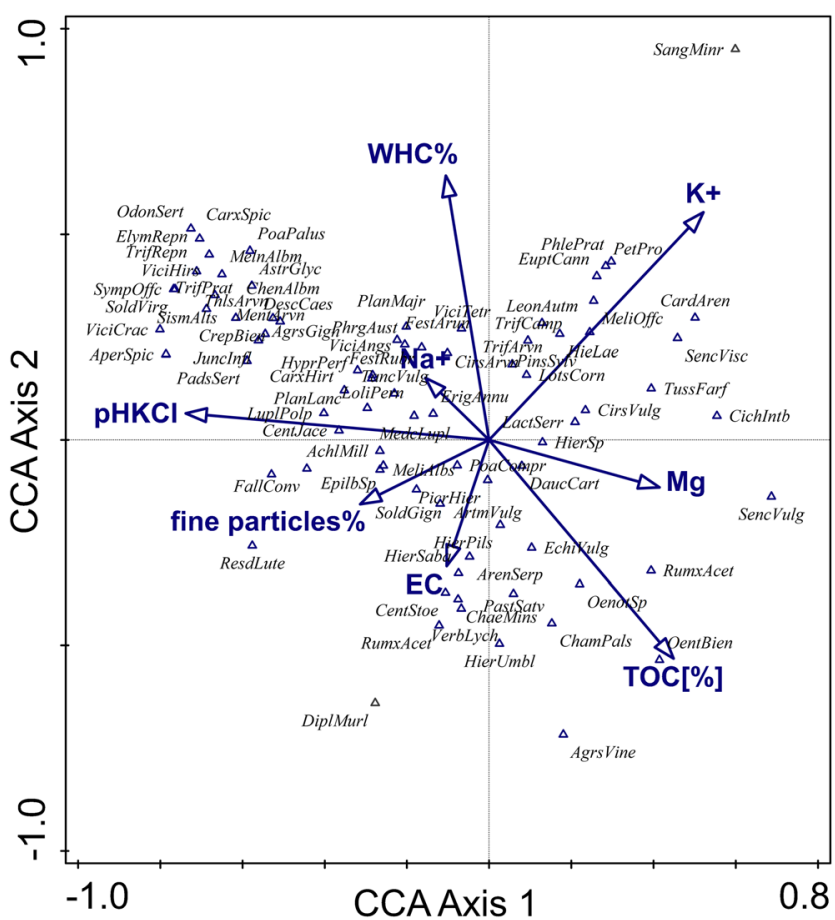

Fig. 4 CCA diagram of plant species and statistically significant physicochemical substrate variables

Eigenvalues Ax. I: 0.20, Ax. II: 0.19, cumulative explained variation: Ax I: 4.01 Ax. II: 7.91. Only the environmental variables found significant in CCA for $p<0.05$ after 999 Monte Carlo permutations were projected in the ordination diagram.

Species abbreviations: AchiMill - Achillea millefolium; AgrsGign - Agrostis gigantea; AgrsVine - Agrostis vinealis; AperSpic - Apera spica-venti; ArenSerp - Arenaria serpyllifolia; ArtmVulg - Artemisia vulgaris; AstrGlyc Astragalus glycyphyllos; CardAren - Cardaminopsis arenosa; CarxHirt - Carex hirta; CarxSpic - Carex spicata; CentJace Centaurea jacea; CentStoe - Centaurea stoebe; ChaeMins Chaenorhinum minus; ChamPals - Chamaenerion palustre; ChenAlbm - Chenopodium album; CichIntb - Cichorium intybus; CirsArvn - Cirsium arvense; CirsVulg - Cirsium vulgare; CrepBien - Crepis biennis; DaucCart - Daucus carota; DescCaes - Deschampsia caespitosa; DiplMurl - Diplotaxis muralis; EchiVulg - Echium vulgare; ElymRepn - Elymus repens; EpilbSp - Epilobium sp.; ErigAnnu - Erigeron annuus; EuptCann - Eupatorium cannabinum; FallConv - Fallopia convolvulus; FestArun - Festuca arundinacea; FestRubr Festuca rubra; HieLae - Hieracium laevigatum; HierPils Hieracium pilosella; HierSaba - Hieracium sabaudum; Epilobium sp.; - Hieracium sp.; HierUmbl - Hieracium umbellatum; HyprPerf - Hypericum perforatum; JuncInfl Juncus inflexus; LactSerr - Lactuca serriola; LeonAutm Leontodon autumnalis; LoliPern - Lolium perenne; LotsCorn - Lotus corniculatus; LuplPolp - Lupulus polyphyllus; OdontSert - Odontites serotina; Medclupl - Medicago lupulina; MeliAlbs - Melilotus albus; Melioff - Melilotus officinalis; MelnAlbm - Melandrium album; MentArve Mentha arvensis; OdonSert - Odontites serotina; OenotSp Oenothera sp.; OentBien - Oenothera biennis; PadsSert Padus serotina; PastSatv - Pastinaca sativa; PetPro Petrorhagia prolifera; Phleprat - Phleum pratense; PhrgAust -Phragmites australis; PicrHier - Picris hieracioides; PinsSylv - Pinus sylvestris; PlanLanc - Plantago lanceolata; PlanMajr Plantago major; PoaCompr - Poa compressa; PoaPalus - Poa palustris; ResdLute - Reseda lutea; RumxAcet - Rumex acetosa; RumxAcet - Rumex acetosella; SangMinr Sanguisorba minor; SencVisc - Senecio viscosus; SencVulg Senecio vulgaris; SismAlts - Sisymbrium altissimum; SoldGign - Solidago gigantea; SoldVirg - Solidago virgaurea; SympOffc - Symphytum officinale; TancVulg - Tanacetum vulgare; ThlsArvn - Thlaspi arvense; TrifArvn - Trifolium arvense; TrifCamp - Trifolium campestre; TrifPrat - Trifolium pratense, TrifRepn - Trifolium repens; TussFarf - Tussilago farfara; VerbLych - Verbascum lychnitis; ViciAngs - Vicia angustifolia; ViciCrac - Vicia cracca; ViciHirs - Vicia hirsuta; ViciTetr Vicia tetrasperma.

\section{Influence of substrate texture on the habitat conditions and diversity of the functional traits of the dominant species}

The number of patches dominated by species representing various socio-ecological groups is uneven and depends on the particle size of the substrate. The analysis (Fig. 5; Appendix 1) showed that among the socio-ecological groups only the dominant species confined to fringes and peatlands were not recorded on all types of substrates. In addition, dominant species which are representative of forests, meadows and grassland habitats are represented only by single patches on silty substrate, and dominant species representing salt marsh vegetation were recorded in only one patch on stony substrate. A significant proportion of those vegetation patches in which the dominant species are representatives of forests (259 patches), meadows (68), grasslands (51), salt marshes (30), karst (53), ruderal (946) and segetal (83) were recorded on gravelly substrates.

The highest number of vegetation patches (214 patches) in which therophytes were the dominant plants was observed on gravelly substrates. Vegetation patches dominated by therophyte species were less frequently recorded on silty (16) and stony (17) substrates. No vegetation patches were observed in which the dominant plant species were represented by the nanophanerophyte life form in substrates with high silt and stone fractions. Only two vegetation patches dominated by chamaephyte 
Table 1 Significant physicochemical variables of the soil substrate that explained the variation of vegetation of coal mine spoil heaps

\begin{tabular}{llll}
\hline Name & Explains \% & Contribution \% & $\mathrm{p}$ \\
\hline $\mathrm{K}^{+}\left(\mathrm{mg} \mathrm{kg}^{-1}\right)$ & 3.1 & 15.1 & 0.002 \\
Total C (TOC (\%)) & 2.8 & 13.5 & 0.002 \\
$\mathrm{pH}$ & 2.3 & 11.0 & 0.002 \\
Available Mg (mg $\left.100 \mathrm{~g}^{-1}\right)$ & 2.0 & 9.8 & 0.002 \\
$\mathrm{WHC}(\%)$ & 1.5 & 7.5 & 0.002 \\
$\mathrm{Na}^{+}\left(\mathrm{mg} \mathrm{kg}^{-1}\right)$ & 1.2 & 6.0 & 0.022 \\
Electrical conductivity EC $\left(\mathrm{mS} \mathrm{cm}^{-1}\right)$ & 1.3 & 6.3 & 0.008 \\
Fine particles $(\%)$ & 1.2 & 5.7 & 0.024 \\
\hline
\end{tabular}

species were recorded on coal mine substrate high in silt particles (Fig. 6).

The highest number of vegetation patches in which ruderals dominated, were recorded on sandy (55 patches) and gravelly (51 patches) substrates. The patches dominated by competitors, stress-tolerant competitors, competitive ruderals and intermediate strategists were most frequent on gravelly substrates $(680,70,340$ and 333 , vegetation patches, respectively). While the vegetation patches dominated by stress-tolerant ruderals (55) were frequently recorded on gravelly substrate (Fig. 7), stress-tolerant competitors and intermediate strategists prevailed on silty substrate.

\section{Discussion}

\section{The relationship between vegetation and soil physicochemical parameters on coal mine spoil heaps}

The structure of the soil substrate and a lack of water and nitrogen have long been cited as probable causes of the difficulties experienced in establishing vegetation cover on the highly industrialized and urban areas of Europe (Horodecki and Jagodziński 2017; Heeney 2018; Woźniak et al. 2018). The abiotic factors are generally considered to be the drivers which shape the vegetation patterns of many terrestrial ecosystems, among which are those that are created on post-industrial and urban sites (Tang et al. 2010; Wang et al. 2011; Wang et al. 2012; Kompała-Baba 2013). It needs to be taken into consideration that the granulometric structure of the soil, influences other physicochemical properties of the soil and the structure of the vegetation diversity. All the elements are linked to different feedbacks interactions both positive and negative ones as well as direct, indirect or conspecific (van der Putten et al. 2013). This complex relationship complicates the clear distinction between the vegetation and physicochemical properties which of them are depended on particle size soil structure. Similarly, in our study we discovered that of the physicochemical soil parameters tested soil substrate texture (granulometric composition) was one of the most important factors that determined vegetation diversity on coal mine spoil heaps. Most species that have been recorded on coal mine spoil heaps in European Industrial

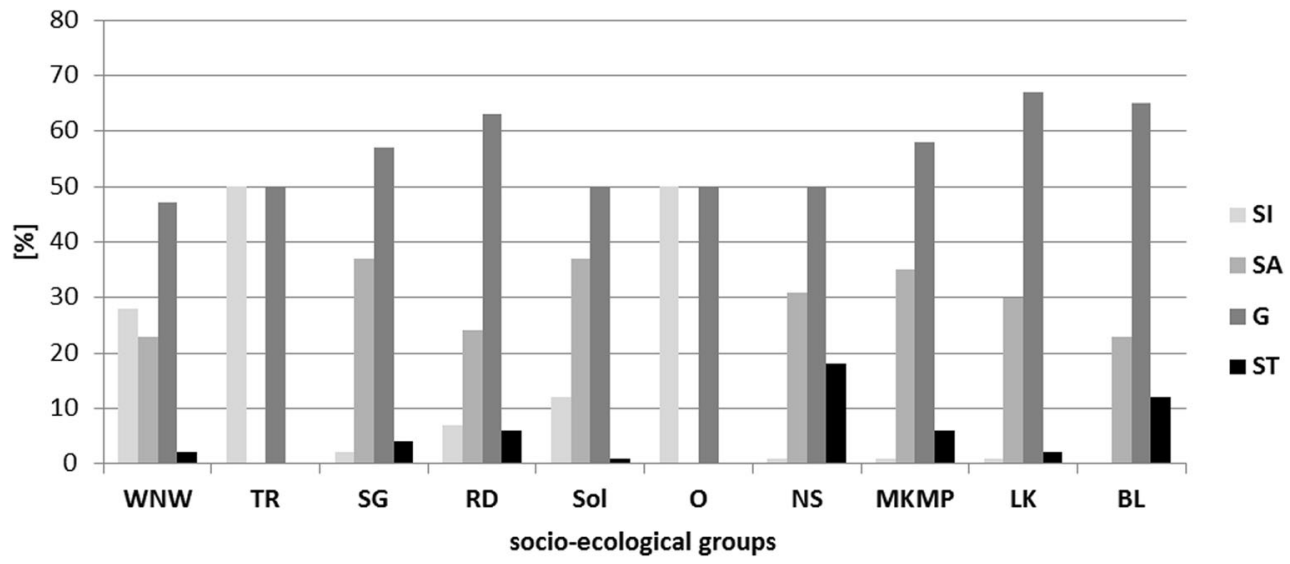

Fig. 5 Percentage participation of vegetation patches dominated by species representing different socio-ecological groups in relation to the texture of the substrate $(\mathrm{G}=203.74 ; p<0.001)$ : $S I-$ Silt, $S A$ - Sand, $G$ Gravel $S T$ - Stones, $B L-$ Forest species: $L K-$ Meadow species, $M K, M P$
- Grassland species: $N S$ - Species of rock habitats, $O$ - Species of clearings and thermophilous fringes, $R D$ - Ruderal species, Sol - Salt marsh species, $S G$ - Segetal species, $T R$ - Peatbog and bog species, $W N W-$ Rush and aquatic species 


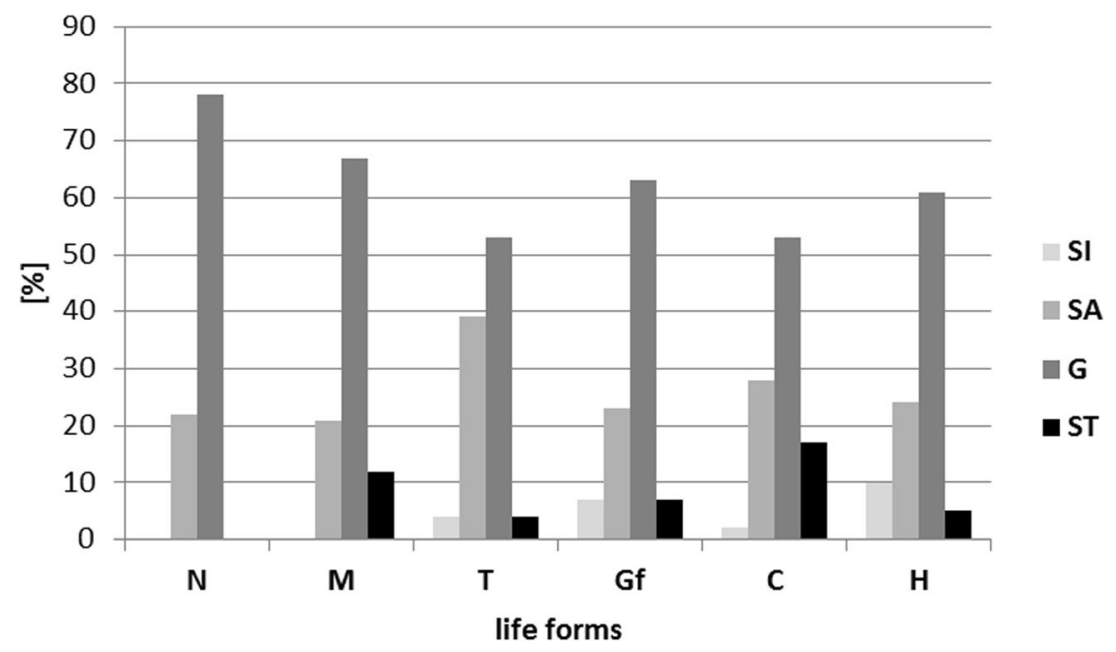

Fig. 6 Percentage participation of vegetation patches dominated by species representing different life forms in relation to different substrates: $S I-$ Silt, $S A$ - Sand, $G-$ Gravel, $S T$ - Stones, $H-$

Region, are mainly native species, however, such industrial habitats are also considered to be valuable substrates for the colonization of rare species (Prach and Pyšek 2001; Rostański 2005, 2006; Woźniak and Kompała 2001; Woźniak et al. 2018). The observed diversity of the spontaneously developing vegetation on the coal mine spoil heaps studied was identified due to the physiognomic distinctiveness of patches of substrate and is reflected in the range of abiotic factors that create a mosaic of different habitats. Futhermore, some species recorded in our study (such as Epipactis helleborine, Filago arvensis, Petrorhagia prolifera, Hieracium xfloribundum), that are considered to be rare, or endangered, in the Silesian voivodeship or are protected in Poland (Urbisz and Parusel 2012).
Hemicryptophytes, $C$ - Chamaephytes, $G f$ - Geophytes, $T-$ Therophytes $M$ - Megaphanerophytes, $N$ - Nanophanerophytes $(\mathrm{G}=$ $148,7 ; p<0.001)$

The granulometric composition of the bedrock, as the basis of coal mine spoil heaps when colonized by plants, depends on the process of weathering of the waste lying on these heaps, which in turn depends to a large extent on the type of rock being stored and its physicochemical properties (Alvarez and Lavado 1998; Acosta et al. 2011). The ongoing process of weathering, the partial segregation of the rock material after depositing it on the heap, as well as the advancement of vegetation succession are constantly changing the proportion of particular soil particles in the soil substrate (Martínez-Ruiz et al. 2001; Cabała et al. 2004; Rostański 2006; Wang et al. 2007; Uroz et al. 2009). Due to the complex petrographic and granulometric structure of the substrate of these heaps,

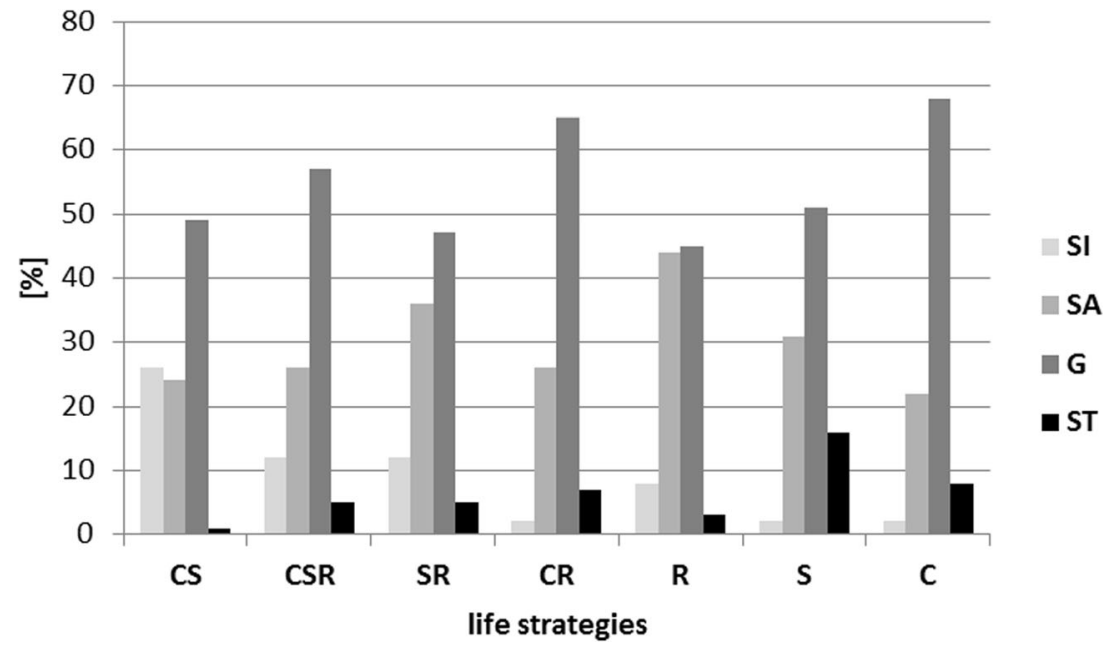

Fig. 7 Percentage participation of vegetation patches dominated by species representing different life strategies in relation to the coarseness of the substrate of spoil heaps: $S I-$ Silt, $S A-$ Sand, $G$ - Gravel, $S T$ -
Stones, $C$ - Competitors, $S$ - Stress-tolerant species, $R$ - Ruderals, $C R$ Competitive ruderals, $S R$ - Stress-tolerant ruderals, $C S R$ - Intermediate strategists, $C S-$ Stress-tolerant competitors $(\mathrm{G}=225.335 ; p<0.001)$ 
soil-based processes are slow and the thickness of the humus/organic layer may vary from a few millimeters (in the initial phase of succession) to several centimeters (in the advanced phases of succession). Changes in the size of the soil substrate particles, as well as the content of some chemical compounds, take place in the shallow layers of the soil substrate at these types of sites (Rostański 2006).

In our study, we associated each recorded vegetation patch with the prevailing particle size fraction in the soil substrate and that enabled us to detect which type of soil texture was most frequently occupied by vegetation. We found that most vegetation patches were confined to predominantly coarser particles in the soil substrate (gravel and sand), whereas only a small portion of the patches developed on fine substrates (silt).

On stony substrate of the studied heaps, tree species such as Betula pendula or Populus tremula, which are commonly considered as habitat-forming species were recorded more frequently. They have many traits, such as rapid juvenile growth, early and usually abundant fruiting every year, anemochory, anemogamy, broad climate and soil tolerances and resistance to environmental pollution (Faliński 1986; Marguí et al. 2007) that enable them to colonise a variety of wastelands. Poor, highly-skeletal (regolithic) soils (with a large proportion of stony and gravelly fractions) are generally hostile habitats for most plants but can, however, be colonized by some rare and endangered species such as Myricaria germanica or Chamaenerion palustre (Woźniak and Rostański 2001; Woźniak 2010; Kompała-Bąba and Bąba 2011).

On gravelly substrate the most frequent dominant species in our study was Calamagrostis epigejos. This expansive, perennial, rhizomatous grass occurs very frequently on anthropogenic sites with a wide spectrum of habitat conditions (Prach and Pyšek 2001; Rebele and Lehman 2001; Prach 2003; Kompała-Bąba et al. 2005; Kompała-Bąba 2013; Woźniak 2005, 2010). By forming dense, compact swards, with a thick layer of dead organic matter, as well as due to occurrence of internal nitrogen cycle, it can create almost monotonous stands and inhibit the development of vegetation patches dominated by other native species (Prach and Pyšek 2001; Rebele and Lehman 2001).

In our study, one quarter of the vegetation patches recorded on sandy substrate was dominated by taxa such as Chenopodium glaucum, Leontodon autumnalis, Oenothera sp., Polygonum aviculare and some grasses Agrostis capillaris, Calamagrostis epigejos and Corynephorus canescens. Most grasses found in anthropogenic plant communities in Upper Silesia were also found to be confined to sandy, clayey or sandyclayey soils (Kompała and Woźniak 2001). In urban habitats, patches with dominant species such as Picris hieracioides, Calamagrostis epigejos, Tussilago farfara or Tanacetum vulgare were confined to sites with a high clay particle size fraction in the soil substrate, whereas patches with Berteroa incana, Eragrostis minor, Helianthus tuberosus, Oenothera biennis, Rubus caesius, and Solidago canadensis developed on sandy substrates and substrates with a low clay particle size content (Kompała-Baba 2013).

On sandy substrate a frequent dominant was a tufted perennial grass, Agrostis capillaris, that can colonise a wide range of habitats both seminatural as well as anthropogenic ones (disturbed areas, roadsides, wetlands, acid grassland, damp soils pasture) (Grime et al. 1988). This species can grow on poorly drained, fine to medium textured soils of $\mathrm{pH} 6.5$ to 7.3 with a moderate level of organic matter (Dale et al. 1965). Agrostis capillaris propagates by way of highly abundant seeds that may persist for 5 years, or more (Thompson et al. 1997) and vegetatively by rhizomes and stolons (Grime et al. 1988; Wilson 1988).

Our research also revealed that on substrates with a high fine particle size fraction, the patches were most commonly dominated by Poa compressa and Phragmites australis and were found in some depressions. The prevalence of a silty substrate is always associated with a slow flow of water, or even temporary water stagnation where along with water leaching, the smallest particles settle in the hollows (Ewing et al. 2012). This is in accordance with our research as we found positive correlations between the participation of the fine particle size fraction, soil moisture and water holding capacity. Poa compressa is a small rhizomatous grass that can establish well in disturbed areas since it reproduces both by seed and rhizomes. Even though Poa compressa is found most often on sunexposed and dry ruderal habitats, it can grow in a wide range of soil types and textures, moderately acidic (pH 5 and 7), nutrient-poor soils and frequently poor drainage, but can also survive periodic flooding (Woźniak 2003; Kompała-Bąba et al. 2005; KompałaBąba and Bąba 2011; St John et al. 2012). Phragmites australis is considered to be an aquatic plant, especially common in alkaline, sometimes salty waters or terrestrial habitats (Tomaszewicz and Podbielkowski 1996; Tang et al. 2006). Its frequent and abundant occurrence on coal mine spoil heaps is difficult to explain. However, its significant relationship to sites with a prevailing small particle size provides a clue. Similarly, in natural and semi-natural habitats, 
Phragmites australis is abundant in vegetation assembled in places where very slow water movement allows the accumulation of fine soil particles (Tomaszewicz and Podbielkowski 1996).

It has also been reported that the presence, and abundance of the finest particle size fractions in soils are connected with the accumulation of some heavy metals ( $\mathrm{Zn}, \mathrm{Pb}, \mathrm{Cd}$ ), and can be responsible for the development of mycorrhiza in sites with strong metal stress (Cabała et al. 2004; Baba et al. 2016). Studies on arbuscular mycorrhizal fungal root colonization dynamics of Molinia caerulea in grasslands and postindustrial sites have revealed that some of its mycorrhizal colonization parameters (mycorrhizal intensity, arbuscular richness) were negatively correlated with the clay and silt fractions in the soil and positively correlated with the percentage of sand fraction where higher species richness and diversity was recorded (Bąba et al. 2016).

The concentration, chemical composition and decomposability of organic matter differs in relation to the composition and mineralogical characteristics of the soil substrate bedrock (Christensen 1992; Christensen 2001). Thus, the mineralogical characteristics of the bedrock influence the differences in soil particle size fractions that represent different microenvironments with regard to nutrients, accessible water and, among other parameters, organic substrates (Hemkemeyer et al. 2018). The share of a particular particle size fraction has a great influence on the permeability of soils, their aeration, reaction, availability of nutrients, cation exchange capacity (Bednarek et al. 2004; Alday et al. 2012), soil fertility and presence and abundance of mycorrhizae (Carrenho et al. 2007).

The soil characteristics, including the relationship between the particle size and organic carbon, have also been frequently studied (Alvarez and Lavado 1998; Harry et al. 2000; Tian et al. 2008; Lü et al. 2011; Alday et al. 2012; Shang et al. 2014). Alday et al. (2012) examined vegetation development during early succession on restored coal wastes in Spain and found that functional and structural changes of the vegetation were related to an accumulation of organic matter, a high sand content and a decrease in $\mathrm{pH}$. In our results we did not find correlations between soil $\mathrm{pH}$, total organic carbon (TOC) and the size of soil particles prevailing in the substrate of the vegetation patches studied. It is probable, that the carbon is of geogenic origin and so is not used by plants. On sites with a higher content of carbon some ruderal (e.g. Echium vulgare), psammophilous (e.g. Oenothera biennis) species, as well as species connected with rock habitats (e.g. Chamaenerion palustre, Chaenorhinum minus) occur.

The weathering process, as well as soil $\mathrm{pH}$, can cause changes in the structure of cations occurring in the material. The $\mathrm{K}^{+}$ions present in the fine particle material, illite layered clay mineral structures and the
$\mathrm{Mg}^{2++}$ ions bound in the montmorillonite structures may be washed out during the process of chemical weathering and can be available for plants. The elution of both ions facilitates the formation of kaolinite-type structures, however, these structures are less favourable due to the formation of soil from carboniferous rocks (Skarżyńska 1997; Patrzałek 2001; Woźniak 2010). The links between the chemical changes in the soil substrate conditions have been reflected in the species composition. In our research, perennial meadow species, as well as ruderal and nitrophilous ones, can be found in sites with higher level of $\mathrm{K}^{+}$and $\mathrm{Mg}^{2+}$. In contrast, a higher level of $\mathrm{Na}^{+}$can be connected with younger heaps (>30 years) (Woźniak 2010). Generally on $\mathrm{Na}^{+}$rich sites more species can be found, including some segetal, ruderal, nitrophilous, meadow and xerothermic ones.

\section{Influence of the soil substrate texture on the diversity and functional traits of the dominant species}

Species richness and species diversity on coal mine spoil heaps in the Upper Silesia are determined by changes in time as well as by different habitat conditions. During succession the values of these indices increase and are highest on the oldest heaps (Rostański 2006; Woźniak 2010). Our results indicate that the structure of the soil substrate affects the species richness as well as the species diversity of the developing vegetation. Significant differences in species richness and species diversity were recorded in the vegetation patches developing on sites with a predominance of the stony fraction in the soil substrate, in comparison to silty fractions. Generally the values of these indices were highest on stony and gravelly substrates. Probably the harsh habitat conditions that occur on silty substrate (lower WHC, lower content of $\mathrm{K}^{+}$ and improper soil texture) caused fewer species to colonise those habitats during development of the vegetation.

The set of functional traits constitute distinct ecological strategies reflecting the evolution and adaptation of plants across diverse environments (Grime 1977; Grime et al. 1988; Westoby et al. 2002). We expected that the traits related to colonizing ability and persistence will be especially important in the development of spontaneous vegetation on coal mine spoil heaps. Usually, ruderals and stress-tolerators appeared at the beginning of succession and later are replaced by competitors (Prach and Pyšek 1999; Caccianiga et al. 2006; Rehounková and Prach 2008; Kompała-Bąba 2013). In our study R-strategists dominated on gravelly and on sandy 
substrates, generally in a smaller number of patches. How it was seen in studies on spontaneous succession in abandoned gravel-sand pits such habitats are frequently hostile for fast growing ruderals, so they do not expand too much during further stages of succession (Roughgarden and Diamond 1986; Prach 1987; van Der Valk 1992; Prach and Pyšek 1999; Řehounková and Prach 2008). We found that with a decrease of stony and gravelly fractions in the soil substrate, there is an increase in the amount of stress-tolerant competitors and intermediate strategists. Harsh physicochemical conditions caused that only species that can survive some stresses (over-drying, compactness of the silt during summer) are able to grow on such sites.

In contrast, the number of patches dominated by competitors as well as species with some mixed strategies (competitive-ruderals, intermediate strategists) increased on substrate with a predominance of gravelly or stony fractions. We should expect that competition will be losing importance on such substrates since they are highly susceptible to erosion, contain non-active material that limits the establishment and growth of plants. Under such conditions, the first plants that establish act as protection ("nurse plants") that facilitates arriving of other species through various mechanisms of substrate fixation (Malkinson et al. 2003; Wiegand et al. 2006).

Analysis of the relationship between the particle size fraction prevailing in the soil substrates, of the studied spoil heaps, and the socio-ecological group of the dominant species in the vegetation patches suggests that it is more strongly related to the type of particle size fraction, than to the soil formation process itself (Martinez-Ruiz and Fernandez-Santos 2005; Martinez-Ruiz and Marrs 2007). Some dominant species were related only to a particular type of substrates such as species connected with clearings and thermophilous fringes and peatlands. The dominant species representative of karst vegetation types were mostly recorded on stony sites. However, most of the dominant species which represent forest and herbaceous vegetation types have been recorded on the whole range of types on the studied sites.

Our results also show that with decreasing of particle size fraction, the participation of megaphanerophytes and chamaephytes decreases, suggesting that silty soil substrates are not appropriate for the development of trees and shrubs, but rather herbaceous vegetation. Significant participation of chamaephytes on young coal mine spoil heaps can be connected with presence of Chamaenerion palustre, that occurred with high frequency and abundance. On sites with the high prevalence of the silty fraction, colonization has mainly been confined to dominant herbaceous species such as Phragmites australis, Puccinellia distans and Poa compressa. This observation is of great practical importance because up until now this factor has not been taken into account during the preparation of land restoration plans (Shang et al. 2014). A higher silt fraction could be expected to have an impact on plant growth, partially because it is able to retain moisture for a longer period of time, but conversely, drought can cause silty substrates to form a very hard shell that is difficult to penetrate by roots of trees and shrubs (Woźniak 1998). A higher sand content results in a lower waterholding capacity that will limit vegetation establishment particularly during prolonged surface droughts in summer months (Tordoff et al. 2000; Alday et al. 2011).

\section{Conclusions}

Knowledge of the relationship between soil physicochemical properties and the diversity and functions of the spontaneously developing vegetation on post-industrial sites is still limited. During time changes in the soil texture as well as in other physicochemical variables take place, that creates mosaic of varied habitats. In such habitats different vegetation types can develop. They are constituted by species (mainly dominant ones) that belong to different life forms, life strategies as well as ecological groups. We found that the dominant particle size fraction in the soil substrate influenced the diversity of the developing vegetation on the coal mine spoil heaps. Fine particle sizes, along with exchangeable cations, water holding capacity, available $\mathrm{Mg}$, electrical conductivity, $\mathrm{pH}$ and total carbon content made the most significant contribution to the variation in the diversity of the spontaneously developing vegetation on the coal mine soil heaps studied. The socioecological group of the dominant species was more strongly related to the type of particle size fraction present in the soil substrate, than to the soil formation process itself. Vegetation patches dominated by nanophanerophytes and chamaephytes were restricted, almost exclusively, to sandy and gravelly sites. Species that were classed as competitors and competitive ruderals were most frequently recorded on gravelly soil substrates. Contrary to our expectations species richness and the values for the diversity indices were not highest in patches with the highest proportion of fine (silty) particles. The granulometric composition of the substrate is important in assessing the course of vegetation development, particularly in man-made sites and also in the land restoration models.

Acknowledgments We are grateful to anonymous referees for their valuable comments and suggestion that enable us to significantly improve to previous version of the manuscript.

\section{Compliance with ethical standards}

Conflict of interest There is no conflict of interest concerning this paper. 


\section{Appendix 1}

Table 2 Descriptive statistics for physico-chemical properties for 119 spoil material samples

\begin{tabular}{lllll}
\hline Variable & Minimum & Median & Mean (SE) & Maximum \\
\hline $\mathrm{pH}_{\mathrm{KCl}}$ & 3.2 & 6.0 & $5.7(0.1)$ & 7.6 \\
Electrical conductivity $\left(\mathrm{mS} \mathrm{cm}^{-1}\right)$ & 0.07 & 0.23 & $0.36(0.03)$ & 2.38 \\
Total C (\%) & 0.1 & 10.4 & $11.3(0.7)$ & 40.5 \\
Total N (\%) & 0.05 & 0.26 & $0.27(0.01)$ & 0.81 \\
Available Mg (mg $\left.100 \mathrm{~g}^{-1}\right)$ & 65.0 & 319.5 & $290.2(10.0)$ & 688.0 \\
Available P (mg $\left.100 \mathrm{~g}^{-1}\right)$ & 0.9 & 10.6 & $14.9(1.1)$ & 64.0 \\
Exchangeable cations: & & & & \\
$\mathrm{Na}^{+}\left(\mathrm{mg} \mathrm{kg}^{-1}\right)$ & 12.8 & 114.8 & $156.0(25.4)$ & 2084.0 \\
$\mathrm{~K}^{+}\left(\mathrm{mg} \mathrm{kg}^{-1}\right)$ & 55.2 & 188.8 & $212.1(8.9)$ & 584.0 \\
$\mathrm{Mg}^{2+}\left(\mathrm{mg} \mathrm{kg}^{-1)}\right.$ & 97.9 & 545.4 & $624.3(41.2)$ & 1440.7 \\
$\mathrm{Ca}^{2+}\left(\mathrm{mg} \mathrm{kg}^{-1}\right)$ & 171.6 & 1712.2 & $2840.2(278.6)$ & 8638.0 \\
\hline
\end{tabular}

\section{Appendix 2}

Table 3 Number of patches dominated by particular species in relation to coarseness of the substratum; $f$ - number of patches. $\%$ - percentage participation of patches dominated by particular species in different coarseness conditions. a - tree layer. $\mathrm{b}-$ shrub layer. $\mathrm{c}-$ herbaceous layer

\begin{tabular}{|c|c|c|c|c|c|c|c|c|c|}
\hline \multirow[t]{3}{*}{ Dominant species } & \multicolumn{8}{|c|}{ Number of patches } & \multirow[t]{3}{*}{ Total of patches } \\
\hline & \multicolumn{2}{|l|}{ Silt } & \multicolumn{2}{|c|}{ Sand } & \multicolumn{2}{|c|}{ Gravel } & \multicolumn{2}{|c|}{ Stones } & \\
\hline & $f$ & $\%$ & $f$ & $\%$ & $f$ & $\%$ & $f$ & $\%$ & \\
\hline Calamagrostis epigejos & 10 & 6.3 & 71 & 10.7 & 162 & 10.3 & 14 & 8.1 & 257 \\
\hline Tussilago farfara & 5 & 3.1 & 48 & 7.3 & 148 & 9.4 & 21 & 12.1 & 222 \\
\hline Betula pendula a & 1 & 0.6 & 34 & 5.1 & 113 & 7.2 & 21 & 12.1 & 169 \\
\hline Betula pendula $b$ & - & - & 15 & 2.3 & 58 & 3.7 & 6 & 3.5 & 79 \\
\hline Betula pendula $c$ & - & - & 6 & 0.9 & 6 & 0.4 & - & - & 12 \\
\hline Poa compressa & 57 & 35.6 & 30 & 4.5 & 51 & 3.2 & 2 & 1.2 & 140 \\
\hline Melilotus alba & 6 & 3.8 & 18 & 2.7 & 85 & 5.4 & 14 & 8.1 & 123 \\
\hline Daucus carota & 1 & 0.6 & 19 & 2.9 & 81 & 5.2 & 13 & 7.5 & 114 \\
\hline Phragmites australis & 33 & $2 . .6$ & 21 & 3.2 & 45 & 2.9 & 2 & 1.2 & 101 \\
\hline Chamaenerion palustre & 2 & 1.3 & 23 & 3.5 & 52 & 3.3 & 17 & 9.8 & 94 \\
\hline Solidago canadensis & - & - & 14 & 2.1 & 67 & 4.3 & 7 & 4.0 & 88 \\
\hline Populus tremula a & - & - & - & - & 9 & 0.6 & 1 & 0.6 & 10 \\
\hline Populus tremula $b$ & - & - & 19 & 2.9 & 43 & 2.7 & 17 & 9.8 & 79 \\
\hline Polygonum aviculare & 10 & 6.3 & 35 & 5.3 & 21 & 1.3 & 1 & 0.6 & 67 \\
\hline Conyza canadensis & - & - & 17 & 2.6 & 44 & 2.8 & 4 & 2.3 & 65 \\
\hline Echium vulgare & - & - & 27 & 4.1 & 31 & 2.0 & 1 & 0.6 & 59 \\
\hline Eupatorium cannabinum & 4 & 2.5 & 14 & 2.1 & 35 & 2.2 & 2 & 1.2 & 55 \\
\hline Agrostis capillaris & 1 & 0.6 & 24 & 3.6 & 20 & 1.3 & - & - & 45 \\
\hline Matricaria maritima subsp.inodora & 1 & 0.6 & 14 & 2.1 & 25 & 1.6 & 2 & 1.2 & 42 \\
\hline Puccinellia distans & 7 & 4.4 & 8 & 1.2 & 20 & 1.3 & 1 & 0.6 & 36 \\
\hline Hieracium pilosella & 1 & 0.6 & 12 & 1.8 & 21 & 1.3 & 1 & 0.6 & 35 \\
\hline Tanacetum vulgare & - & - & 4 & 0.6 & 28 & 1.8 & - & - & 32 \\
\hline Lotus corniculatus & - & - & 2 & 0.3 & 29 & 1.8 & - & - & 31 \\
\hline Solidago gigantea & - & - & 5 & 0.8 & 20 & 1.3 & - & - & 25 \\
\hline Chenopodium rubrum & 2 & 1.3 & 9 & 1.4 & 14 & 0.9 & - & - & 25 \\
\hline Reynoutria japonica & - & - & 3 & 0.5 & 18 & 1.1 & 3 & 1.7 & 24 \\
\hline Lepidium ruderale & - & - & 8 & $1 . .2$ & 12 & $0 . .8$ & 2 & 1.2 & 22 \\
\hline Rubus caesius & - & - & - & - & 21 & 1.3 & - & - & 21 \\
\hline Diplotaxis muralis & - & - & 8 & 1.2 & 12 & 0.8 & - & - & 20 \\
\hline Trifolium arvense & - & - & 4 & 0.6 & 12 & 0.8 & - & - & 16 \\
\hline Alopecurus geniculatus & 4 & 2.5 & 5 & $0 . .8$ & 7 & 0.4 & - & - & 16 \\
\hline Agrostis stolonifera & - & - & 3 & 0.5 & 11 & 0.7 & 1 & 0.6 & 15 \\
\hline
\end{tabular}


Table 3 (continued)

Dominant species

Number of patches

Total of patches

\begin{tabular}{|c|c|c|c|c|c|c|c|c|c|}
\hline & \multicolumn{2}{|l|}{ Silt } & \multicolumn{2}{|l|}{ Sand } & \multicolumn{2}{|c|}{ Gravel } & \multicolumn{2}{|c|}{ Stones } & \\
\hline & $f$ & $\%$ & $f$ & $\%$ & $f$ & $\%$ & $f$ & $\%$ & \\
\hline Helianthus tuberosus & - & - & 1 & $0 . .2$ & 14 & $0 . \backslash .9$ & - & - & 15 \\
\hline Quercus robur a & - & - & 6 & 0.9 & 7 & 0.4 & 1 & 0.6 & 14 \\
\hline Atriplex prostrata & - & - & 9 & 1.4 & 5 & 0.3 & - & - & 14 \\
\hline Typha angustifolia & 2 & 1.3 & 6 & 0.5 & 8 & 0.5 & - & - & 13 \\
\hline Chenopodium glaucum & 4 & 2.5 & 6 & 0.9 & 3 & 0.2 & - & - & 13 \\
\hline Echinochloa crus-galli & - & - & 5 & 0.8 & 7 & 0.4 & 1 & 0.6 & 13 \\
\hline Senecio viscosus & - & - & 8 & 1.2 & 3 & 0.2 & 2 & 1.2 & 13 \\
\hline Clematis vitalba & - & - & 5 & 0.8 & 7 & 0.4 & - & - & 12 \\
\hline Pteridium aquilinum & - & - & 7 & 1 & 1.5 & 0.3 & - & - & 12 \\
\hline Cirsium arvense & - & - & 1 & 0.2 & 9 & 0.6 & 1 & 0.6 & 11 \\
\hline Datura stramonium & - & - & 1 & $0 . .2$ & 10 & 0.6 & - & - & 11 \\
\hline Lactuca serriola & - & - & 6 & 0.9 & 5 & 0.3 & - & - & 11 \\
\hline Reynoutria xbohemica & - & - & 1 & 0.2 & 9 & 0.6 & - & - & 10 \\
\hline Salsola kali & - & - & 5 & 0.8 & 5 & 0.3 & - & - & 10 \\
\hline Rumex acetosella & - & - & 1 & 0.2 & 6 & 0.4 & 2 & 1.2 & 9 \\
\hline Centaurea stoebe & - & - & 3 & 0.5 & 4 & 0.3 & 1 & 0.6 & 8 \\
\hline Cerastium arvense & - & - & 4 & $0 . .6$ & 4 & 0.3 & - & - & 8 \\
\hline Erigeron anпuиs & - & - & 1 & 0.2 & 6 & 0.4 & 1 & 0.6 & 8 \\
\hline Amaranthus retroflexus & - & - & 2 & 0.3 & 4 & 0.3 & 1 & 0.6 & 7 \\
\hline Arenaria serpyllifolia & - & - & 1 & 0.2 & 6 & 0.4 & - & - & 7 \\
\hline Chenopodium album & - & - & 2 & 0.3 & 4 & 0.3 & 1 & 0.6 & 7 \\
\hline Epilobium lamyi & - & - & 5 & 0.8 & 2 & 0.1 & - & - & 7 \\
\hline Equisetum arvense & - & - & - & - & 5 & 0.3 & 2 & 1.2 & 7 \\
\hline Molinia caerulea & - & - & - & - & 7 & 0.4 & - & - & 7 \\
\hline Reseda lutea & - & - & 3 & 0.5 & 2 & 0.1 & 2 & 1.2 & 7 \\
\hline Arrhenatherum elatius & - & - & 2 & 0.3 & 4 & 0.3 & - & - & 6 \\
\hline Digitaria sanguinalis & - & - & 3 & 0.5 & 2 & $0 . .1$ & 1 & 0.6 & 6 \\
\hline Jasione montana & - & - & 4 & 0.6 & 2 & 0.1 & - & - & 6 \\
\hline Eragrostis minor & - & - & 2 & 0.3 & 4 & 0.3 & - & - & 6 \\
\hline Picris hieracioides & - & - & 2 & 0.3 & 4 & 0.3 & - & - & 6 \\
\hline Pinus sylvestris a & - & - & - & - & 5 & 0.3 & - & - & 5 \\
\hline Pinus sylvestris $b$ & - & - & 2 & 0.3 & 2 & 0.1 & 2 & 1.2 & 6 \\
\hline Schoenoplectus lacustris & - & - & - & - & 6 & 0.4 & - & - & 6 \\
\hline Corynephorus canescens & - & - & 5 & 0.8 & - & - & - & - & 5 \\
\hline Calluna vulgaris & - & - & 3 & 0.5 & 2 & 0.1 & - & - & 5 \\
\hline Potentilla intermedia & - & - & 3 & 0.5 & 2 & 0.1 & - & - & 5 \\
\hline Robinia pseudoacacia a & - & - & - & - & 5 & 0.3 & - & - & 5 \\
\hline Quercus rubra a & - & - & 1 & 0.2 & 4 & 0.3 & - & - & 5 \\
\hline Bidens tripartita & - & - & 1 & 0.2 & 3 & 0.2 & - & - & 4 \\
\hline Calystegia sepium & - & - & 3 & 0.5 & 1 & 0.1 & - & & 4 \\
\hline Chenopodium botrys & - & - & 1 & 0.2 & 3 & 0.2 & - & - & 4 \\
\hline Hypericum perforatum & - & - & 3 & 0.5 & 1 & 0.1 & - & - & 4 \\
\hline Solanum nigrum & - & - & 1 & 0.2 & 3 & 0.2 & - & - & 4 \\
\hline Alnus glutinosa $b$ & - & - & - & - & 4 & 0.3 & - & - & 4 \\
\hline Typha latifolia & 3 & 1.9 & 4 & 0.6 & 2 & 0.1 & - & - & $*$ \\
\hline Total & 160 & - & 662 & - & 1572 & - & 173 & - & 2567 \\
\hline Mean & 7.62 & - & 7.79 & - & 14.83 & - & 4.68 & - & - \\
\hline SD & 13.27 & - & 11.56 & - & 27.76 & - & 6.19 & - & - \\
\hline Min & 1 & - & 1 & - & 1 & - & 1 & - & - \\
\hline $\operatorname{Max}$ & 57 & - & 71 & - & 162 & - & 21 & - & - \\
\hline Number of dominants & 21 & - & 85 & - & 106 & - & 37 & - & - \\
\hline
\end{tabular}


Open Access This article is distributed under the terms of the Creative Commons Attribution 4.0 International License (http:// creativecommons.org/licenses/by/4.0/), which permits unrestricted use, distribution, and reproduction in any medium, provided you give appropriate credit to the original author(s) and the source, provide a link to the Creative Commons license, and indicate if changes were made.

Publisher's note Springer Nature remains neutral with regard to jurisdictional claims in published maps and institutional affiliations.

\section{References}

Acosta JA, Martinez-Martinez S, Faz A, Arocena J (2011) Accumulations of major and trace elements in particle size fractions of soils on eight different parent materials. Geoderma 161:30-42. https://doi.org/10.1016/j.geoderma.2010.12.001

Alday JG, Marrs RH, Martínez-Ruiz C (2011) Vegetation succession on reclaimed coal wastes in Spain: the influence of soil and environmental factors. Appl Veg Sci 14:84-94

Alday JG, Marrs RH, Martínez-Ruiz C (2012) Soil and vegetation development during early succession on restored coal wastes: a 6 year permanent plot study. Plant Soil 353:305-320. https://doi.org/10. 1007/s11104-011-1033-2

Alvarez R, Lavado RS (1998) Climate, organic matter and clay content relationships in the Pampa and Chaco soils, Argentina. Geoderma 83(1-2):127-141. https://doi.org/10.1016/S0016-7061(97)00141-9

Bąba W, Błońska A, Kompała-Bąba A, Małkowski Ł, Ziemer B, Sierka E, Nowak T, Woźniak G, Besenyei L (2016) Arbuscular mycorrhizal fungi (AMF) root colonization dynamics of Molinia caerulea (L.) Moench. In grasslands and post-industrial sites. Ecol Eng 95:817827. https://doi.org/10.1016/j.ecoleng.2016.07.013

Bednarek R, Dziadowiec H, Pokojska U, Prusinkiewicz Z (2004) Badania ekologiczno-gleboznawcze. Wydawnictwo Naukowe PWN, Warszawa

Bradshaw AD (1997) Restoration of mined lands using natural processes. Ecol Eng 8(4):255-269. https://doi.org/10.1016/S0925-8574(97) 00022-0

Bradshaw AD (2000) The use of natural processes in reclamation - advantages and difficulties. Landscape Urban Plan 51:89-100. https:// doi.org/10.1016/S0169-2046(00)00099-2

Cabała J, Teper E, Teper L, Rostański A, Małkowski E (2004) Mineral composition in rhizosphere of plants grown in the vicinity of a $\mathrm{Zn}$ $\mathrm{Pb}$ ore flotation tailings pond. Preliminary study. Acta Biol Cracov Ser Bot 46:65-74

Caccianiga M, Luzzaro A, Pierce S, Ceriani RM, Cerabolini B (2006) The functional basis of a primary succession resolved by CSR classification. Oikos 112(1):10-20

Carrenho R, Trufem SFB, VLR B, Silva ES (2007) The effect on different soil properties on arbuscular mycorrhizal colonization of peanuts, sorghum and maize. Acta Bot Bras 21(3):723-730. https://doi.org/ 10.1590/S0102-33062007000300018

Chen FS, Zeng DH, Zhou B, Sing AN, Fan ZP (2006) Seasonal variation in soil nitrogen availability under Mongolian pine plantations at the Keerqin sand lands, China. J Arid Environ 67:226-239 https://doi. org/10.1016/j.jaridenv.2006.02.017

Christensen BT (1992) Physical fractionation of soil and organic matter in primary particle size and density separates. Adv Soil Sci 20:1-90. https://doi.org/10.1007/978-1-4612-2930-8-1

Christensen BT (2001) Physical fractionation of soil and structural and functional complexity in organic matter turnover. Eur J Soil Sci 52: 345-353. https://doi.org/10.1046/j.1365-2389.2001.00417.x
Dale HM, Harrison PJ, Thomson GW (1965) Weeds as indicators of physical site characteristics in abandoned pastures. Can J Bot 43(11):1319-1327

Ewing JM, Vepraskas MJ, Broome SW, White JG (2012) Changes in wetland soil morphological and chemical properties after 15, 20, and 30 years of agricultural production. Geoderma 179-180:7380. https://doi.org/10.1016/j.geoderma.2012.02.018

Faliński JB (1986) Vegetation dynamics in temperate lowland primeval forests. In: Ecological studies in Białowieża Forest, Geobotany 8, Dr W. Junk publishers, Dordrecht-Boston-Lancaster

Frank D, Klotz S (1990) Biologisch-ökologische Daten zur Flora der DDR. Wissenschaftliche Beiträge der Martin-Luther Universität Halle-Wittenberg, Halle

Gao YZ, Wang SP, Han XG, Chen QS, Wang YF, Zhou ZY, Zhang SM, Yang J (2004) Soil nitrogen regime and the relationship between aboveground green phytobiomass and soil nitrogen fractions at different stocking rates in the Xilin river basin, Inner Mongolia. Acta Phytoecol Sinica 28(3):285-293

Grime JP (1977) Evidence for the existence of three primary strategies in plants and its relevance to ecological and evolutionary theory. Am Nat 111(982):1169-1194

Grime JP (1979) Plant strategies and vegetation processes. Wiley, Sons, Chichester, Ltd., Chichester-New York-Brisbane-Toronto. https:// doi.org/10.1007/BF02895358

Grime JP, Hodgson JG, Hunt R (1988) Comparative plant ecology: a functional approach to common British species. (Agrostis spp.). Unwin Hyman, London, pp 58-65

Harry JP, Roger LP, Neal AS (2000) Factors controlling soil carbon levels in New Zealand grasslands: is clay content important? Soil Sci Soc Am J 64(5):1623-1630. https://doi.org/10.2136/sssaj2000. $6451623 \mathrm{x}$

Heeney G (2018) The post-industrial landscape as site for creative practice: Material memory. Cambridge Scholar Publishing, Newcastle upon Tyne

Hemkemeyer M, Dohrmann AB, Christensen BT, Tebbe CC (2018) Bacterial preferences for specific soil particle size fractions revealed by community analyses. Front Microbiol 9:149. https://doi.org/10. 3389/fmicb.2018.00149

Herrmann SM, Hutchinson CF (2005) The changing contexts of the desertification debate. J Arid Environ 63(3):538-555. https://doi.org/ 10.1016/j.jaridenv.2005.03.003

Hopmans P, Bauhus J, Khanna P, Weston C (2005) Carbon and nitrogen in forest soils: potential indicators for sustainable management of eucalypt forests in South-Eastern Australia. Forest Ecol Manag 220(1-3):75-87. https://doi.org/10.1016/j.foreco.2005.08.006

Horodecki P, Jagodziński AM (2017) Tree species effects on litter decomposition in pure stands on afforested post-mining sites. For Ecol Manag 406:1-11. https://doi.org/10.1016/j.foreco.2017.09.059

Dell Inc (2016). Dell Statistica (data analysis software system), version 13. software.dell.com

Jasik M, Małek S, Żelazny M (2017) Effect of water stage and tree stand composition on spatiotemporal differentiation of spring water chemistry draining Carpathian flysch slopes (Gorce Mts). Sci Total Enviro 599-600:1630-1637. https://doi.org/10.1016/j.scitotenv. 2017.05.079

Katz A, Thompson AH (1985) Fractal sandstone pores: implications for conductivity and pore formation. Phys Rev Lett 54(12):1325. https://doi.org/10.1103/PhysRevLett.54.1325

Klotz S, Kühn I, Durka W (2002) BIOLFLOR — Eine Datenbank zu biologisch-ökologischen Merkmalen der Gefäßpflanzen in Deutschland. In: Schriftenreihe für Vegetationskunde, 38. Bundesamt für Naturschutz, Bonn

Kompała A, Woźniak G (2001) The role of grasses in chosen anthropogenic plant communities in the upper Silesia Industrial District. In: L. Frey (ed), Studies on grasses in Poland W. Szafer Institute of Botany, Polish Academy of Sciences, Kraków, pp 329-353 
Kompała-Bąba A (2013) Abiotic and biotic factors affecting the diversity of ruderal vegetation (Silesian uplands Poland). Sorus, Poznań

Kompała-Baba A, Baba W (2011) Udział traw w zbiorowiskach roślinnych wykształcających się na obszarze wybranych kamieniołomów Wyżyny Śląskiej. Fragm Flor Geobot Polonica 18(2):359-374

Kompała-Bąba A, Błońska A, Bąba W, Czyba M (2005) Grasses in the plant communities which develop on the waste sites of zinc-lead industry (upper Silesia, S Poland). In: Frey L (ed) Biology of grasses in Poland W. Szafer Institute of Botany, Polish Academy of Sciences, Kraków, pp 269-282

Li J, Zhao Y, Liu H, Su Z (2016) Sandy desertification cycles in the southwestern mu Us Desert in China over the past 80 years recorded based on nebkha sediments. Aeolian Res 20:100-107 https://doi. org/10.1016/j.aeolia.2015.12.003

Lobe I, Amelung W, Du Preez CC (2001) Losses of carbon and nitrogen with prolonged arable cropping from sandy soils of the south African Highveld. Eur J Soil Sci 52(1):93-101. https://doi.org/10. 1046/j.1365-2389.2001.t01-1-00362.x

Lü SQ, Gao P, Geng GP, Zhang J, Xia JB (2011) Characteristics of soil particles and their correlation with soil organic matter in lowlands of the Yellow River delta. J Soil Water Conserv 25(6):134-138

Malkinson D, Kadmon R, Cohen D (2003) Pattern analysis in successional communities - an approach for studying shifts in ecological interactions. J Veg Sci 14:213-222. https://doi.org/10.1111/j.16541103.2003.tb02146.x

Marguí E, Queralt I, Carvalho ML, Hidalgo M (2007) Assessment of metal availability to vegetation (Betula pendula) in $\mathrm{Pb}-\mathrm{Zn}$ ore concentrate residues with different features. Environ Pollut 145(1):179184. https://doi.org/10.1016/j.envpol.2006.03.028

Martinez-Ruiz C, Fernandez-Santos B (2005) Natural revegetation on topsoiled uranium-mining spoils according to the exposure. Acta Oecol 28:231-238

Martinez-Ruiz C, Marrs RH (2007) Some factors affecting successional change on uranium mine wastes: insights for ecological restoration. App Veg Sci 10:333-342

Martínez-Ruiz C, Fernández-Santos BJM, Gómez-Gutiérrez JM (2001) Effects of substrate coarseness and exposure on plant succession in uranium-mining wastes. Plant Ecol 155:79-89. https://doi.org/10. 1023/A:1013208305393

Mirek Z, Piękoś-Mirkowa H, Zając A, Zając M (2002) Flowering plants and pteridophytes of Poland. A checklist. Krytyczna lista roślin naczyniowych Polski. Szafer Institute of Botany. Polish Academy of Sciences, Kraków

Oberdorfer E, Muller T, Korneck D, Lippert W, Markgarf-Dannenberg I, Patzke E, Weber HE (1990) Pflanzensoziologische Excursionsflora, 6 Auflage edn. Ulmer, Stuttgart. https://doi.org/10.1002/fedr. 19911020525

Ostrowska A, Gawliński S, Szczubiałka Z (1991) Metody analizy i oceny właściwości gleb i roślin: katalog. IOŚ

Oyonarte C, Aranda V, Durante P (2008) Soil surface properties in Mediterranean mountain ecosystems: effects of environmental factors and implications of management. Forest Ecol Manag 254(2): 156-165. https://doi.org/10.1016/j.foreco.2007.07.034

Patrzałek A (2001) Właściwości gleby inicjalnej powstającej na zwałowisku odpadów karbońskich. Zeszyty Naukowe Politechniki Ślaskiej. Seria: Górnictwo 248:151-156

Pieczyrak J (2010) Characteristics and engineering usage of wastes from coal mining. ACEE 1:77-84

Piekarska-Stachowiak A, Szary M, Ziemer B, Besenyei L, Woźniak G (2014) An application of the plant functional group concept to restoration practice on coal mine spoil heaps. Ecol Res 29:843-853. https://doi.org/10.1007/s11284-014-1172-z

PN ISO 11277:2005. Soil Quality - Determination of Particle Size Distribution in Mineral Soil Material Method by Sieving and
Sedimentation. Polish Committee for Standardization. https:// www.iso.org/standard/54151.html. Accessed 08 December 2018

Prach K (1987) Succession of vegetation on dumps from strip coal mining. N.W. Bohemia. Czechoslovakia. Folia Geobot Phytotaxon 22: 339-354. https://doi.org/10.1007/BF02853231

Prach K (2003) Spontaneous succession in central-European man-made habitats: what information can be used in restoration practice? App Veg Sci 6(2):125-129

Prach K, Pyšek P (1999) How do species dominating in succession differ from others? J Veg Sci 10(3):383-392

Prach K, Pyšek P (2001) Using spontaneous succession for restoration of human-disturbed habitats: experience from Central Europe. Ecol Eng 17:55-62. https://doi.org/10.1016/S0925-8574(00)00132-4

Prach K, Pyšek P, Bastl M (2001) Spontaneous vegetation succession in human-disturbed habitats: a pattern across seres. App Veg Sci 4(1): 83-88. https://doi.org/10.1111/j.1654-109X.2001.tb00237.x

R Core Team (2018) R A Language and Environment for Statistical Computing. R Foundation for Statistical Computing, Vienna. URL: www.r-project.org

Rebele F, Lehmann C (2001) Biological Flora of Central Europe: Calamagrostis epigejos (L.) Roth. Flora 196 (5):325-344. https:// doi.org/10.1016/S0367-2530(17)30069-5

Řehounková K, Prach K (2008) Spontaneous vegetation succession in gravel-sand pits: a potential for restoration. Restoration Ecol 16(2): 305-312. https://doi.org/10.11111/j.1526-100X.2007.00316x

Rostański A (2005) Specific feature of the flora of colliery spoil heaps in selected European region. Polish Bot Stud 19:97-103

Rostański A (2006) Spontaniczne kształtowanie się pokrywy roślinnej na zwałowiskach po górnictwie wegla kamiennego na Górnym Śląsku. Wydawnictwo Uniwersytetu Śląskiego Nr 2410, Katowice

Roughgarden J, Diamond J (1986) Overview: the role of species interaction in community ecology. In: Diamond J, Case TJ (eds) Community ecology. Harper, Row, New York

Rutherford PM, McGill WB, Arocena JM, Figueiredo CT (2006) Total Nitrogen. In: Carter MR, Gregorich EG (eds) Soil sampling and methods of analysis, 2nd edn. CRC Press, Boca Raton, Florida, pp 267-278

Schimel JP, Bennett J (2004) Nitrogen mineralization: challenges of a changing paradigm. Ecology 85(3):591-602. https://doi.org/10. 1890/03-8002

Shang S, Jiang P, Chang SX, Song Z, Liu J, Sun L (2014) Soil organic carbon in particle size and density fractionations under four forest vegetation-land use types in subtropical China. Forests 5:13911408. https://doi.org/10.3390/f5061391

Simard RR (1993) Ammonium acetate extractable elements. In: Martin R, Carter S (eds) Soil sampling and methods of analysis' Lewis Publisher, Florida, pp 39-43

Skarżyńska KM (1997) Odpady powęglowe i ich zastosowanie w inżynierii lądowej i wodnej. Wydawnictwo Akademii Rolniczej, Krakow

Skurczyńska M, Leśniok M (2008). Przyroda województwa śląskiego. Biblioteka CDPGŚ. http://przyroda.katowice.pl/pl/przyrodanieozywiona/klimat/127-klima [Access 14.11.2018]

Song L, Zhu J, Li M, Zhang J, Lv L (2016) Sources of water used by Pinus sylvestris var. mongolica trees based on stable isotope measurements in a semiarid Sandy region of Northeast China. Agr Water Manage 164:281-290. https://doi.org/10.1016/j.agwat.2015.10. 018(2016)

St John L, Tilley D, Winslow S (2012). Plant guide for Canada bluegrass (Poa compressa). USDA-Natural Resources Conservation ServiceUSDA

Strzyżowski D, Fidelus-Orzechowska J, Żelazny M (2018) Sediment transport by uprooting in the forested part of the Tatra Mountains, southern Poland. Catena 160:329-338. https://doi.org/10.1016/j. Catena.2017.09.019 
Szczepańska J (1987) Zwałowiska odpadów górnictwa węgla kamiennego jako ogniska zanieczyszczeń środowiska wodnego. Zesz Nauk AGH w Krakowie. No 1135 Geologia 35

Talik E, Guzik A, Małkowski E, Woźniak G, Sierka E (2018) Biominerals and waxes of Calamagrostis epigejos and Phragmites australis leaves from post-industrial habitats. Protoplasma 255(3):773-784. https://doi.org/10.1007/s00709-017-1179-8

Tang N, Cui BS, Zhao XS (2006) The restoration of reed (Phragmites australis) wetland in the Yellow River Delta. Acta Ecol Sinica 26(8): 2616-2624. https://doi.org/10.1007/s00267-011-9757-6

Tang B, Liu SR, Cai DX, Lu LH, He RM, Gao YX, Di WZ (2010) Soil physical and chemical characteristics under different vegetation restoration patterns in China south subtropical area. Chin J Appl Ecol 21(10):2479-2486. https://doi.org/10.5846/stxb201111151734

ter Braak CJF, Smilauer P (2012) CANOCO reference manual and user's guide software for ordination, version 5.0. Microcomputer power, Ithaca, $\mathrm{p} 496$

Thompson K, Bakker JP, Bekker RM (1997) The soil seed banks of north West Europe: methodology, density and longevity. Cambridge University Press, New York, p 276

Tian JQ, Zhou ZY, Bao B, Sun JX (2008) Variations of soil particle size distribution with land-use types and influences on soil organic carbon and nitrogen. J Plant Ecol 32(3):601-610 https://doi.org/10. 3773/j.issn. 1005-264x.2008.03.009

Tichý L, Holt J (2006) JUICE program for management, analysis and classification of ecological data. Masaryk University, Brno, Vegetation Science Group

Tomaszewicz H, Podbielkowski Z (1996). Zarys hydrobotaniki. PWN Warszawa

Tordoff GM, Baker AJM, Willis AJ (2000) Current approaches to the revegetation and reclamation of metalliferous mine wastes. Chemosphere 41:219-228. https://doi.org/10.1016/S00456535(99)00414-2

Tropek R, Cizek O, Kadlec T, Klecka J (2017) Habitat use of Hipparchia semele (Lepidoptera) in its artificial stronghold: necessity of the resource-based habitat view in restoration of disturbed sites. Pol J Ecol 65(3):385-399. https://doi.org/10.3161/15052249PJE2017.65.3.006

Urbisz A, Parusel JB (2012) Czerwona lista roślin naczyniowych województwa śląskiego. In: Raport o stanie przyrody województwa śląskiego. Raporty Opinie 6.2. Centrum Dziedzictwa Przyrody Górnego Ślaska, Katowice, pp 105177 in Polish

Uroz S, Calvaruso C, Turpault MP, Frey-Klett P (2009) Mineral weathering by bacteria: ecology, actors and mechanisms. Trends Microbiol 17:378-387. https://doi.org/10.1016/j.tim.2009.05.004

van der Putten WH, Bardgett RD, Bever JD, Bezemer TM, Casper BB, Fukami T, Kardol P, Klironomos JN, Kulmatiski A, Schweitzer JA, Suding KN, van der Voorde TFJ, Wardle DA (2013) Plant-soil feedbacks: the past, the present and future challenges. J Ecol 101:265276. https://doi.org/10.1111/1365-2745.12054

Van Der Valk AG (1992) Establishment, colonization and persistence. In: Glenn-Lewin DC, Peet RK, Veblen TT (eds) Plant succession. Theory and prediction. Population and community biology, Series, vol 11. Chapman, Hall, London, pp 60-102

Wang Y, Wang KL, Zhou DS, Li L, Chen ZH (2007) Effects of vegetation succession on soil quality in karst region of Guangxi, China. J Soil Water Conserv 21(6):130-134. https://doi.org/10.5846/ stxb201506041124

Wang LY, Han YZ, Zhang CL, Pei ZY (2011) Reclaimed soil properties and weathered gangue change characteristics under various vegetation types on gangue pile. Acta Ecol Sinica 31(21):6429-6441

Wang Y, Liu JS, Wang JD, Sun CY (2012) Effects of wetland reclamation on soil nutrient losses and reserves in Sanjiang plain, Northeast China. J Integrative Agric 11(3):512-520. https://doi.org/10.1016/ S2095-3119(12)60037-9

Watkins NW, Freeman MP (2008) Natural complexity. Science 320:323-324
Westoby M, Falster DS, Moles AT, Vesk PA, Wright IJ (2002) Plant ecological strategies: some leading dimensions of variation between species. Annu Rev Ecol Syst 33(1):125-159

Wiegand T, Kissling WD, Cipriotti PA, Aguiar MR (2006) Extending point pattern analysis to objects of finite size and irregular shape. J Ecol 94:825-837. https://doi.org/10. 1111/j.1365-2745.2006.01113.x

Wiegleb G, Felinks B (2001) Primary succession in post mining landscapes of lower Lusatia - chance or necessity. Ecol Eng 17:199217. https://doi.org/10.1016/S0925-8574(00)00159-2

Wilson JB (1988) The cost of heavy-metal tolerance: an example. Evolution 42(2):408-413

Woźniak G (1998) Primary succession on the sedimentation pools of coal mine. Synanthropization of plant cover in new polish research. Phytocoenosis 10(9):189-198

Woźniak G (2003) Grass-dominated plant communities of the postindustrial waste sites in the upper Silesia. In: Frey L (ed) Problems of grass biology, W. Szafer Institute of Botany. Polish Academy of Sciences, Kraków, pp 531-545

Woźniak G (2005) Problems of Calamagrostis epigejos synecology in post-industrial sites. In: Frey L (ed) Biology of grasses in Poland W. Szafer Institute of Botany, Polish Academy of Sciences, Kraków, pp 353-361

Woźniak G (2010). Diversity of vegetation on coal-mine heaps of the upper Silesia (Poland). Szafer Institute of Botany, Polish Academy of Sciences, Kraków

Woźniak G, Cohn EVJ (2007) Monitoring of spontaneous vegetation dynamics on post coal mining waste sites in Upper Silesia, Poland. Geotechnical and Environmental Aspects of Waste Disposal Sites Proceedings of Green 4 International Symposium on Geotechnics Related to the Environment pp. 289-294

Woźniak G, Kompała A (2001) Ecology of spontaneous vegetation on post-industrial waste lands (Upper Silesia-Poland). In: Sarsby RW, Meggyes T (eds) Green 3. The exploitation of natural resources and the consequences. Thomas Telford, London, pp 568-573

Woźniak G, Rostański A (2001) Chamaenerion palustre SCOP, as a frequent apophyte in plant communities of post-industrial waste site. Natura Silesiae Superioris, Suplement: 55-66

Woźniak G, Markowicz A, Borymski S, Piotrowska-Seget Z, Chmura D, Besenyei L (2015) The relationship between successional vascular plant assemblages and associated microbial communities on coal mine spoil heaps. Community Ecol 16(1):23-32. https://doi.org/ 10.1556/168.2015.16.1.3

Woźniak G, Sierka E, Wheeler A (2018) Urban and industrial habitats: how important they are for ecosystem services. In: Levente Hufnagel L (ed) Ecosystem Services and Global Ecology. https:// doi.org/10.5772/intechopen. 75723

Zalibekov ZG (2002) Changes in the soil cover as a result of desertification. Eurasian Soil Sci 35(12):1276-1281

Zarzycki K, Trzcińska-Tacik H, Różański W, Szelag Z, Wołek J, Korzeniak U (2002) Ecological indicator values of vascular plants of Poland. Ekologiczne liczby wskaźnikowe roślin naczyniowych Polski. Szafer Institute of Botany. Polish Academy of Sciences, Kraków

Zeng DH, Hu YL, Chang SX, Fan ZP (2009) Land cover change effects on soil chemical and biological properties after planting Mongolian pine (Pinus sylvestris var. mongolica) in sandy lands in Keerqin, northeastern China. Plant Soil 317(1-2):121-133. https://doi.org/ 10.1007/s11104-008-9793-Z

Zhang JY, Zhao HL (2009) Changes in soil particles fraction and their effects on stability of soil-vegetation system in restoration processes of degraded sandy grassland. Ecol Environ Sci 18(4):1395-1401

Zhu JK (2003) Regulation of ion homeostasis under salt stress. Curr Opin Plant Biol 6(5):441-445. https://doi.org/10.1016/S1369-5266(03) 00085-2 